\title{
Modelling future changes in surface ozone: a parameterized approach
}

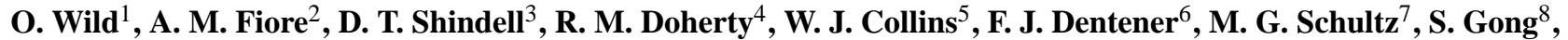 \\ I. A. MacKenzie ${ }^{4}$, G. Zeng ${ }^{9}$, P. Hess ${ }^{10}$, B. N. Duncan ${ }^{11}$, D. J. Bergmann ${ }^{12}$, S. Szopa ${ }^{13}$, J. E. Jonson ${ }^{14}$, T. J. Keating ${ }^{15}$, \\ and A. Zuber ${ }^{16}$ \\ ${ }^{1}$ Lancaster Environment Centre, Lancaster University, Lancaster, UK \\ ${ }^{2}$ NOAA Geophysical Fluid Dynamics Laboratory, Princeton, NJ, USA \\ ${ }^{3}$ NASA Goddard Institute for Space Studies and Columbia University, New York, NY, USA \\ ${ }^{4}$ School of GeoSciences, University of Edinburgh, UK \\ ${ }^{5}$ Met Office Hadley Centre, Exeter, UK \\ ${ }^{6}$ European Commission, Joint Research Centre, Institute for Environment and Sustainability, Ispra, Italy \\ ${ }^{7}$ IEK-8, Forschungszentrum-Jülich, Germany \\ ${ }^{8}$ Science and Technology Branch, Environment Canada, Toronto, ON, Canada \\ ${ }^{9}$ National Institute of Water and Atmospheric Research, Lauder, New Zealand \\ ${ }^{10}$ Department of Biological and Environmental Engineering, Cornell University, Ithaca, New York, USA \\ ${ }^{11}$ NASA Goddard Space Flight Center, Greenbelt, MD, USA \\ ${ }^{12}$ Atmospheric Earth and Energy Division, Lawrence Livermore National Laboratory, CA, USA \\ ${ }^{13}$ Laboratoire des Sciences du Climat et de l'Environnement, Gif-sur-Yvette, France \\ ${ }^{14}$ Norwegian Meteorological Institute, Oslo, Norway \\ ${ }^{15}$ Office of Policy Analysis and Review, Environmental Protection Agency, Washington D.C., USA \\ ${ }^{16}$ European Commission, Directorate General Environment, Brussels, Belgium \\ Correspondence to: O. Wild (o.wild@lancaster.ac.uk)
}

Received: 19 September 2011 - Published in Atmos. Chem. Phys. Discuss.: 11 October 2011

Revised: 28 January 2012 - Accepted: 6 February 2012 - Published: 21 February 2012

\begin{abstract}
This study describes a simple parameterization to estimate regionally averaged changes in surface ozone due to past or future changes in anthropogenic precursor emissions based on results from 14 global chemistry transport models. The method successfully reproduces the results of full simulations with these models. For a given emission scenario it provides the ensemble mean surface ozone change, a regional source attribution for each change, and an estimate of the associated uncertainty as represented by the variation between models. Using the Representative Concentration Pathway (RCP) emission scenarios as an example, we show how regional surface ozone is likely to respond to emission changes by 2050 and how changes in precursor emissions and atmospheric methane contribute to this. Surface ozone changes are substantially smaller than expected with the SRES A1B, A2 and B2 scenarios, with annual global mean reductions of as much as 2 ppb by 2050 vs. increases of 4-6 ppb under SRES, and this reflects the assumptions of more stringent precursor emission controls under the RCP
\end{abstract}

scenarios. We find an average difference of around $5 \mathrm{ppb}$ between the outlying RCP 2.6 and RCP 8.5 scenarios, about $75 \%$ of which can be attributed to differences in methane abundance. The study reveals the increasing importance of limiting atmospheric methane growth as emissions of other precursors are controlled, but highlights differences in modelled ozone responses to methane changes of as much as a factor of two, indicating that this remains a major uncertainty in current models.

\section{Introduction}

Increases in anthropogenic emissions of ozone precursors are believed to make a substantial contribution to the rising levels of surface ozone $\left(\mathrm{O}_{3}\right)$ observed at many long-term measurement stations over past decades (Oltmans et al., 2006). As a strong oxidant detrimental to human health and damaging to plant growth and crop yields, surface $\mathrm{O}_{3}$ contributes to

Published by Copernicus Publications on behalf of the European Geosciences Union. 
poor air quality and to economic and environmental damage. Understanding the reasons for its growth presents a considerable challenge, as the balance of natural and anthropogenic, regional and global changes contributing to its growth varies greatly over the globe and remains poorly characterized (e.g. Lelieveld and Dentener, 2000; Sudo and Akimoto, 2007). While surface $\mathrm{O}_{3}$ is often considered a regional pollutant that can be addressed with regional-scale precursor emission controls, it is also a global pollutant that can influence air quality over intercontinental scales (e.g. Akimoto, 2003; TFHTAP, 2010). It remains unclear how regional emission controls aimed at reducing surface $\mathrm{O}_{3}$ may be offset by global "background" $\mathrm{O}_{3}$ increases, by changes in the abundance of longer-lived $\mathrm{O}_{3}$ precursors such as methane $\left(\mathrm{CH}_{4}\right)$ or by changes in chemical processing or transport driven by future shifts in climate (Fiore et al., 2009; Jacob and Winner, 2009; TF-HTAP, 2010). Understanding the anthropogenic contribution to changes in surface $\mathrm{O}_{3}$ requires a sufficiently good understanding of the chemical and dynamical processes controlling $\mathrm{O}_{3}$ and the sources and fates of its precursors to explain observed changes, and hence to reduce the current uncertainty in our estimates of future changes in $\mathrm{O}_{3}$ affecting air quality and climate.

This study explores the contribution of changes in anthropogenic $\mathrm{O}_{3}$ precursor emissions to changes in the regional and global abundance of surface $\mathrm{O}_{3}$. It describes a simple approach to quantify surface $\mathrm{O}_{3}$ changes based on regional precursor emission changes derived from global chemical transport model simulations from a recent model intercomparison. This is applied to past and future emission scenarios to explore the range of surface $\mathrm{O}_{3}$ responses expected over different parts of the world and to provide a source attribution for these changes. The approach provides a measure of the uncertainty in the estimated responses as represented by the variation over the 14 independent models contributing to the study. We start by describing and evaluating the parameterization used in Sects. 2-4, and test it with historical emission changes in Sect. 5. We then explore a range of future emission scenarios in Sect. 6, quantifying the uncertainty in the expected $\mathrm{O}_{3}$ changes and providing a regional source attribution for these changes. We conclude by suggesting how the approach introduced here may be used to inform emission controls targeting air quality.

\section{Model simulations and emission scenarios}

Under the Convention on Long-range Transboundary Air Pollution (LRTAP), the task force on Hemispheric Transport of Air Pollution (HTAP) was established to develop a fuller understanding of the transport of a range of key air pollutants over intercontinental scales (TF-HTAP, 2007). A series of multi-model intercomparison experiments was coordinated by HTAP to provide a consistent quantification of intercontinental source-receptor relationships between major
Table 1. Standard and additional simulations for the HTAP model intercomparison showing number of models contributing results for $\mathrm{O}_{3}$.

\begin{tabular}{lrrrrr}
\hline Perturbation & None & $\mathrm{NO}_{\mathrm{x}}$ & VOC & $\mathrm{CO}$ & All \\
\hline Control run & 24 & & & & \\
Methane run & 18 & & & & \\
North America & & 18 & 16 & 15 & 19 \\
Europe & & 18 & 16 & 15 & 19 \\
South Asia & & 18 & 13 & 14 & 19 \\
East Asia & & 18 & 15 & 15 & 20 \\
Global & & 9 & 9 & 9 & 10 \\
\hline
\end{tabular}

industrialised regions. Global and regional models of atmospheric chemistry and transport were run with 2001 meteorological conditions and with best estimates of natural and anthropogenic emissions and a specified atmospheric abundance of $\mathrm{CH}_{4}(1760 \mathrm{ppb})$, and these provided monthly mean distributions of $\mathrm{O}_{3}$ and aerosol and their precursors for the year. A simulation with $20 \%$ reduced atmospheric concentrations of $\mathrm{CH}_{4}$ was performed to determine the impacts of $\mathrm{CH}_{4}$ abundance on $\mathrm{O}_{3}$ in each model, and this was followed by a further series of runs with $20 \%$ reductions in annual anthropogenic emissions of the main $\mathrm{O}_{3}$ precursors, nitrogen oxides $\left(\mathrm{NO}_{\mathrm{x}}\right)$, carbon monoxide $(\mathrm{CO})$ and volatile organic compounds (VOCs), individually and together, over each of the four main continental scale regions of interest in turn, see Fig. 1. Each model was run for one year, with additional time (typically six months) as spin-up. A response matrix was then generated to quantify the impact of each emission change over each source region on each receptor region in each model, and the resulting source-receptor relationships for $\mathrm{O}_{3}$ and its precursors are outlined in the HTAP assessment reports (TF-HTAP, 2007, 2010) and are explored in further detail elsewhere (Sanderson et al., 2008; Shindell et al., 2008; Fiore et al., 2009).

For the present study, an additional set of four runs were defined with $20 \%$ global emission reductions for each precursor so that the effects of emission changes outside the four HTAP regions, the Rest-of-World response, can be considered. The number of data sets from distinct models or model/meteorology combinations that were contributed for each simulation is summarised in Table 1. Each of these data sets provides the monthly mean spatial distribution of $\mathrm{O}_{3}$ changes over the global domain for the specified emission change, allowing continental-scale source-receptor relationships to be derived.

The models contributing to the HTAP intercomparison were run with their own best estimates of emissions for 2001 conditions. Recent studies of future surface $\mathrm{O}_{3}$ have typically used emission scenarios from the Special Report on Emissions Scenarios (SRES) generated for Intergovernmental Panel on Climate Change (IPCC) assessment reports. 


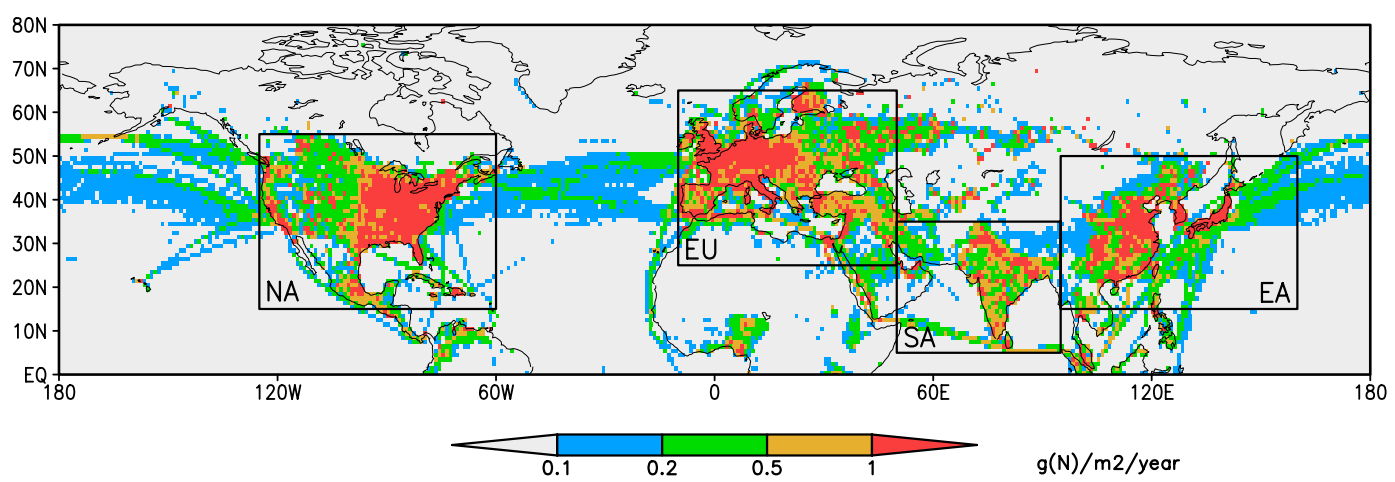

Fig. 1. Anthropogenic surface $\mathrm{NO}_{\mathrm{x}}$ emissions $\left(\mathrm{g} \mathrm{N} \mathrm{m}^{-2} \mathrm{yr}^{-1}\right)$ for year 2000 from Lamarque et al. (2010) showing the HTAP source-receptor regions considered here: N. America, Europe, S. Asia and E. Asia.

Three of the four scenario families introduced (A1, A2 and B2) show large increases in $\mathrm{O}_{3}$ precursor emissions that reach or exceed a factor of two, and previous assessments of future air quality consequently show very large increases in future $\mathrm{O}_{3}$ that exceed $30 \mathrm{ppb}$ in many regions by 2100 (e.g. Prather et al., 2003). In the present study we contrast these with the new Representative Concentration Pathways (RCP) generated for the Climate Model Intercomparison Project (CMIP5) simulations for the IPCC fifth assessment report along with harmonized historical emissions from 1850 to 2000 from Lamarque et al. (2010). Emissions of $\mathrm{O}_{3}$ precursors are available from 2000 to 2100 along each RCP pathway, and we use these along with the specified changes in atmospheric $\mathrm{CH}_{4}$ abundance. The four RCP scenarios represent different assumptions about climate change mitigation measures, and are labelled by the levels of radiative forcing reached by 2100: RCP 2.6 (also referred to as RCP 3-PD), RCP 4.5, RCP 6.0 and RCP 8.5 (van Vuuren et al., 2011; Thomson et al., 2011; Masui et al., 2011; Riahi et al., 2011). Air pollution control policies are assumed to evolve under the different scenarios, and emissions of most $\mathrm{O}_{3}$ precursors decline by 2050 , although more strongly in the cleaner RCP 2.6 scenario than in the high radiative forcing RCP 8.5 scenario, and with substantial differences in regional distribution. We note that the four RCP scenarios represent possible future emission pathways, but have been developed independently and are governed by different assumptions about social, economic and political development. Differences in the treatment of $\mathrm{CH}_{4}$ emissions, in particular, lead to large differences in the atmospheric $\mathrm{CH}_{4}$ concentrations used here, and we show that this has important consequences for tropospheric $\mathrm{O}_{3}$.

\section{Parameterizing ozone responses}

In this study we use model results from the HTAP intercomparison to quantify the impact of a realistic range of changes in anthropogenic precursor emissions on surface $\mathrm{O}_{3}$ on a global, regional and sub-regional basis. The approach involves scaling surface $\mathrm{O}_{3}$ responses derived from $20 \%$ emission reductions by the fractional emission change for a given emission scenario over each region for each precursor. For each model the HTAP results provide the monthly mean $\mathrm{O}_{3}$ change, $\Delta \mathrm{O}_{3}(i, j, k)$, over each receptor region, $k$, for a $20 \%$ reduction in emissions, $E_{i j}$, of each precursor, $i$, over each source region, $j$. The atmospheric $\mathrm{CH}_{4}$ abundance in these model runs was fixed at $1760 \mathrm{ppb}$, and so we are not able to explore the effect of $\mathrm{CH}_{4}$ emission changes; however, we use model runs with $20 \%$ reduced $\mathrm{CH}_{4}$ abundance $(1408 \mathrm{ppb})$ to determine the regional $\mathrm{O}_{3}$ response to $\mathrm{CH}_{4}$ changes, $\Delta \mathrm{O}_{3 \mathrm{~m}}(k)$. The monthly mean $\mathrm{O}_{3}$ response over each region, $\Delta \mathrm{O}_{3}(k)$, is then calculated by summing the individual responses for each of the three precursors $\left(\mathrm{NO}_{\mathrm{x}}\right.$, $\mathrm{CO}$ and VOC) over the five regions encompassing all global sources (N. America, Europe, S. Asia, E. Asia and Rest-ofWorld) and including the response from the change in global $\mathrm{CH}_{4}$ abundance:

$\Delta \mathrm{O}_{3}(k)=\sum_{i=1}^{3} \sum_{j=1}^{5} f_{i j} \Delta \mathrm{O}_{3}(i, j, k)+f_{\mathrm{m}} \Delta \mathrm{O}_{3 \mathrm{~m}}(k)$

The scale factor for the $\mathrm{O}_{3}$ response to each regional precursor emission change, $f_{i j}$, is dependent on the emission scenario and is given by the ratio of the fractional emission change, $\Delta E_{i j} / E_{i j}$, to the $20 \%$ emission change applied in the HTAP simulations:

$f_{i j}=\frac{\Delta E_{i j}}{0.2 \times E_{i j}}$

Similarly, the scale factor for the $\mathrm{CH}_{4}$ response, $f_{\mathrm{m}}$, is given by the ratio of the global abundance change, $\Delta \mathrm{CH}_{4}$, to the $20 \%$ abundance change:

$f_{\mathrm{m}}=\frac{\Delta \mathrm{CH}_{4}}{0.2 \times\left[\mathrm{CH}_{4}\right]}$

These scale factors vary linearly with the size of the applied emission change or change in $\mathrm{CH}_{4}$ abundance. This simple linear combination of individual regional $\mathrm{O}_{3}$ responses 
a)
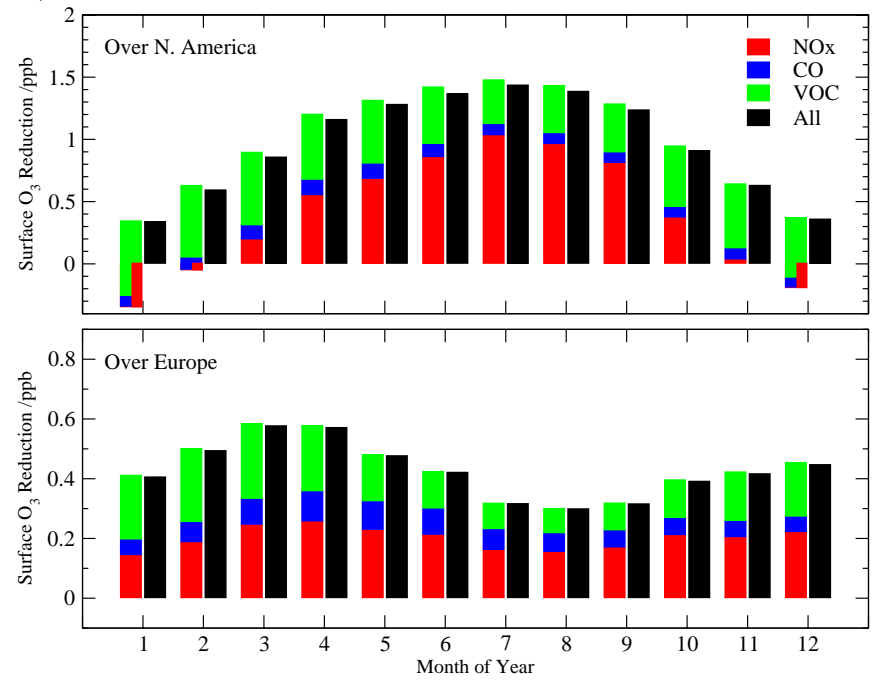

b)

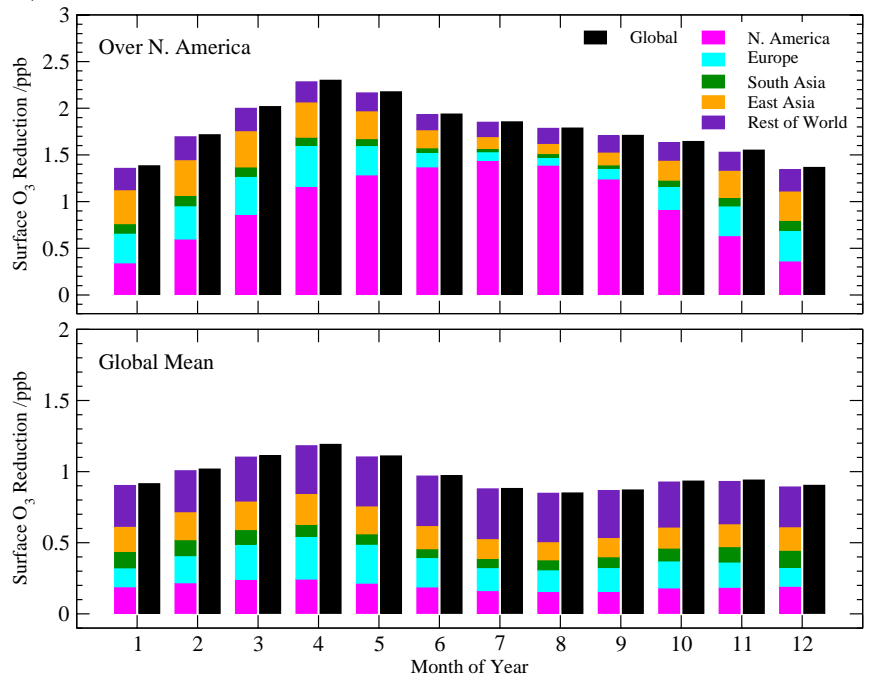

Fig. 2. Tests of linearity with the FRSGC/UCI CTM. (a) Sum of $\mathrm{O}_{3}$ responses from $20 \%$ reductions in anthropogenic $\mathrm{NO}_{\mathrm{x}}$, $\mathrm{CO}$ and VOC emissions from North American sources compared with responses from a combined $20 \%$ emissions change, shown over the source region (upper panel) and a distant receptor region (Europe, lower panel). The contribution from $\mathrm{NO}_{\mathrm{x}}$ is negative over the source region in winter, partly compensating for the effects of $\mathrm{CO}$ and VOC emissions. (b) Sum of $\mathrm{O}_{3}$ responses from combined $20 \%$ emission reductions over each of the HTAP regions and over the rest of the world compared with the response from a global emission change, shown over a single region (N. America, upper panel) and over the globe (lower panel).

works well for small emission changes, and is applicable to larger changes with only minor modifications to account for the small degree of nonlinearity inherent in $\mathrm{O}_{3}$ chemistry at the continental scales considered here, described below.

A major advantage of this combinatorial approach is its computational simplicity, allowing regional and global $\mathrm{O}_{3}$ changes to be explored for a wide range of different emission scenarios. Equation (1) can be applied to each atmospheric model in turn to generate a range of $\mathrm{O}_{3}$ responses that reflect the uncertainties in emissions, chemistry and transport over the contributing models. The approach can be used to determine where the largest uncertainties arise, pinpointing model weaknesses, and to identify emission scenarios that would be of most interest to explore in further detail with full model simulations. In addition, the approach provides an immediate regional source attribution for $\mathrm{O}_{3}$ changes, something not readily available from full model simulations without a tracer tagging scheme, such as that outlined in Grewe et al. (2010), or further sensitivity studies.

\section{Testing the approach}

To test the validity of the approach and quantify the errors involved, results from the HTAP intercomparison are supplemented here by additional simulations using one of the contributing models, the Frontier Research System for Global Change version of the University of California, Irvine chemical transport model, FRSGC/UCI CTM (Wild et al., 2003).
Ozone responses due to individual precursor emission changes are used here in preference to those due to combined changes in $\mathrm{NO}_{\mathrm{x}}, \mathrm{CO}$ and VOC emissions as many models also included changes in aerosol in the combined runs. However, changes in tropospheric photochemistry, particularly through the abundance of the hydroxyl radical, $\mathrm{OH}$, couple the effects of these precursor changes such that the $\mathrm{O}_{3}$ responses are not independent. Over the coarse temporal and spatial scales considered here the effects of the three individual precursor emission changes are almost linearly additive, as noted in Fiore et al. (2009), with the fractional error, $\epsilon_{\mathfrak{c}}$, given by

$\epsilon_{\mathrm{c}}=\frac{\sum_{i=1}^{3} \Delta \mathrm{O}_{3}(i)-\Delta \mathrm{O}_{3 \mathrm{c}}}{\Delta \mathrm{O}_{3 \mathrm{c}}}$

where $\Delta \mathrm{O}_{3 \mathrm{c}}$ is the ozone response from the combined emission change. Figure 2 shows that the sum of the $\mathrm{O}_{3}$ responses from each of the $20 \%$ precursor emission changes in North American sources closely matches the response from the combined emissions change on a month by month basis, both over the source region itself and over a downwind receptor region. The regional monthly responses from the sum of separate emission changes are marginally larger than those from the combined emission changes, by $2-7 \%$ over the source region and by less than $2 \%$ over receptor regions. Fractional errors are largest over the source region in winter where $\mathrm{NO}_{\mathrm{x}}$ emission reductions lead to enhancement in $\mathrm{O}_{3}$ due to reduced titration by $\mathrm{NO}$, but the absolute $\mathrm{O}_{3}$ response 
is small in this season. $\mathrm{NO}_{\mathrm{x}}$ emission reductions provide the largest $\mathrm{O}_{3}$ response but lower the abundance of $\mathrm{OH}$, and hence the $\mathrm{O}_{3}$ response of $\mathrm{CO}$ and $\mathrm{VOC}$ reductions is less when all three precursors are reduced together. Larger errors may be expected to occur on smaller spatial scales close to urban source regions which are more greatly influenced by rapid chemical processing and which may show strongly non-linear responses, but these effects are not seen at the continental scales considered here, where behaviour is close to linear.

Rest-of-world $\mathrm{O}_{3}$ responses are required here to account for changes in emissions outside the four HTAP regions. These are derived by subtracting the response due to emissions from each region from that of a global emissions change. To test the validity of this, additional simulations were performed with the FRSGC/UCI CTM applying $20 \%$ anthropogenic precursor emission reductions everywhere outside the HTAP regions for each of the precursors in turn. The fractional error, $\epsilon_{\mathrm{g}}$, between the sum of the $\mathrm{O}_{3}$ response over the five individual regions and the $\mathrm{O}_{3}$ response to a global reduction, $\Delta \mathrm{O}_{3 \mathrm{~g}}$, is given by:

$\epsilon_{\mathrm{g}}=\frac{\sum_{k=1}^{5} \Delta \mathrm{O}_{3}(k)-\Delta \mathrm{O}_{3 \mathrm{~g}}}{\Delta \mathrm{O}_{3 \mathrm{~g}}}$

Figure 2 shows the difference between the sum of the regional and rest-of-world $\mathrm{O}_{3}$ responses and the response to global emission changes. Over major source regions the response to local emissions dominates and shows a strong seasonality, while the global average response is more uniform. The differences are less than $2 \%$ in all regions except for wintertime in Europe where they reach $4 \%$ due to non-linear responses associated with the greater prevalence of $\mathrm{O}_{3}$ titration in this region.

The $20 \%$ emission perturbations applied in the HTAP studies were chosen to be small enough to give an approximately linear response while being sufficiently large to provide robust signals in all models. However, the response of $\mathrm{O}_{3}$ to its precursor emissions is known to be non-linear (e.g. Lin et al., 1988), and it is important to characterize where these non-linearities become significant. Scaling a $20 \%$ emission reduction by a factor of five has been shown to underestimate the response to a $100 \%$ reduction (Wu et al., 2009), and while this underestimation is relatively small for VOC emissions, generally less than $10 \%$, it can exceed a factor of two for $\mathrm{NO}_{\mathrm{x}}$ emissions (Wu et al., 2009; Grewe et al., 2010), and shows a strong seasonal dependence (Wu et al., 2009). For this reason the sensitivity approach used in the HTAP studies is unsuitable for deriving a full source apportionment for $\mathrm{O}_{3}$. However, it does not preclude its use in estimating the impact of less severe emission changes.

To determine the limits of the linear scaling, additional simulations were performed with the FRSGC/UCI CTM for $\mathrm{NO}_{\mathrm{x}}$ emission changes ranging from complete removal to a doubling of anthropogenic emissions. We focus on emissions from Europe, where deviation from linear behaviour is greatest due to higher latitudes and thus lower insolation which lead to substantial wintertime titration of surface $\mathrm{O}_{3}$. Figure 3 shows the $\mathrm{O}_{3}$ responses over the European source region and over a receptor region (N. America) along with the errors associated with linearly scaling a $20 \%$ emission reduction. Non-linear behaviour is clear, particularly over the source region where annual regional mean $\mathrm{O}_{3}$ is at a maximum in this model, and where additional wintertime titration exceeds summertime production for any further increase in $\mathrm{NO}_{\mathrm{x}}$ emissions. However, the nonlinearity is relatively small for small emission changes, and the error in scaling $20 \%$ changes remains below $1 \mathrm{ppb}$ under emission changes of up to $\pm 60 \%$. In all cases a linear scaling leads to overestimation of $\mathrm{O}_{3}$, reflecting the curvature of the $\mathrm{O}_{3}$ response shown in Fig. 3, and indicating that the magnitude of any $\mathrm{O}_{3}$ change will be underestimated for emission reductions and overestimated for emission increases. Large departures from linearity are typically confined to emission reductions of more than $60 \%$, roughly equivalent to a return to $\mathrm{NO}_{\mathrm{x}}$ emissions for 1950 over Europe and N. America and to 1970 emissions over South and East Asia. Over downwind receptor regions the nonlinear behaviour is weaker, and the fractional error is similar throughout the year so that the largest errors are present in April when the contributions from Europe are greatest. Note that the errors identified here apply to the effects of $\mathrm{NO}_{\mathrm{x}}$ emission changes in isolation; simultaneous changes in $\mathrm{CO}$ and VOC emissions of a similar magnitude reduce the nonlinearity substantially. Complete removal of all anthropogenic emissions over Europe leads to an overestimate of $3 \mathrm{ppb}$ over the source region using the linear scaling compared with the $6 \mathrm{ppb}$ overestimate seen here from removal of $\mathrm{NO}_{\mathrm{x}}$ emissions alone.

To account for the nonlinearity in $\mathrm{O}_{3}$ response to larger $\mathrm{NO}_{\mathrm{x}}$ emission changes shown in Fig. 3, we replace the scale factor, $f$, in Eq. (1) with a new factor, $g$, which has a quadratic dependence on $f$ :

$g=0.95 f+0.05 f^{2}$

This provides a small amount of curvature equivalent to an incremental reduction of $10 \%$ in the $\mathrm{O}_{3}$ response for each successive $20 \%$ emission increase. The terms in this quadratic are chosen to provide a fit to the curves for the full CTM simulations shown in Fig. 3 (upper panels), and reduce the errors in the monthly $\mathrm{O}_{3}$ response by $20-60 \%$ for $\mathrm{NO}_{\mathrm{x}}$ emission changes of up to $60 \%$, as shown in Fig. 3 (lower panels). For emission reductions greater than $60 \%$ this correction remains insufficient, and we do not expect the parameterization to work as well under these conditions. The approach is also insufficient to represent the response in source regions under titration regimes where an emission reduction may lead to an increase in $\mathrm{O}_{3}$, as seen in January in Fig. 3. Under these conditions we limit the $\mathrm{O}_{3}$ response by replacing $f$ in Eq. (1) with $2 f-g$ for emission reductions, 
European impacts on Europe
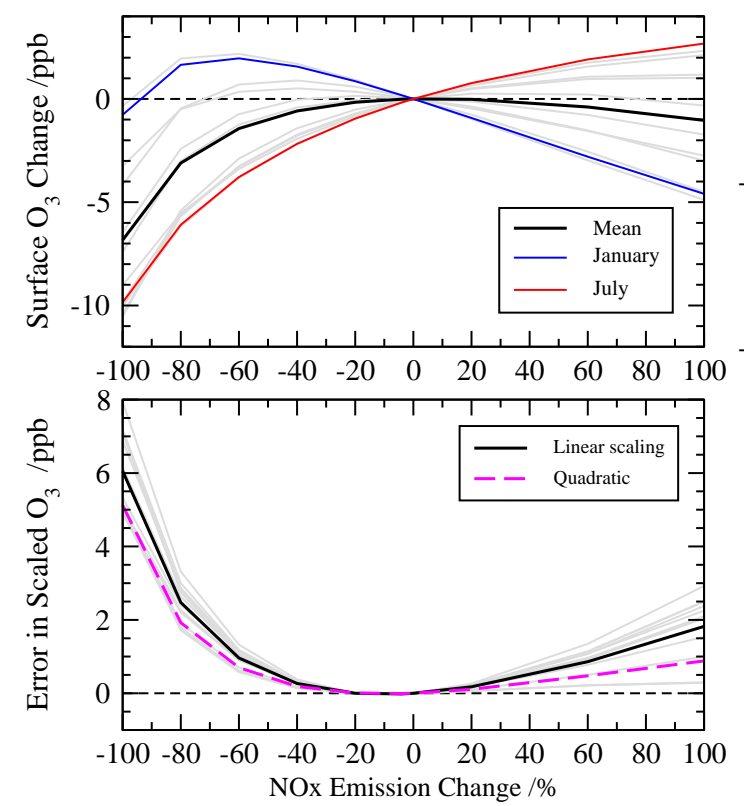

European impacts on North America
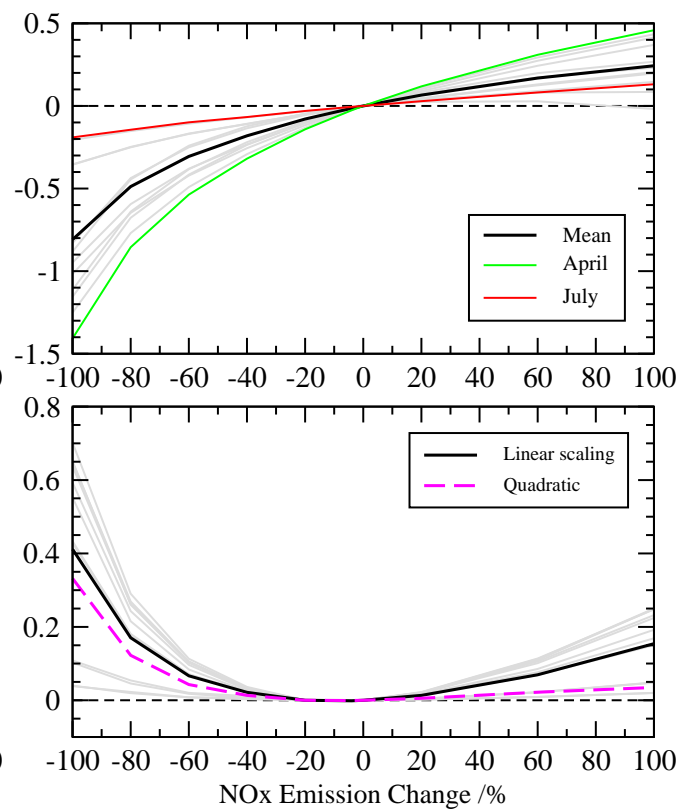

Fig. 3. Sensitivity of monthly $\mathrm{O}_{3}$ changes in the FRSGC/UCI CTM to the magnitude of European $\mathrm{NO}_{\mathrm{x}}$ emissions relative to current conditions over the source region (left) and a downwind receptor region (N. America, right). Annual mean $\mathrm{O}_{3}$ responses are shown in black and individual months in grey; months with the largest and smallest responses are highlighted. The lower panels show the error associated with linearly scaling a $20 \%$ emission perturbation over the source and receptor regions (annual error in black, monthly errors in grey, scale factor "f") and using a quadratic scaling (annual error in magenta, scale factor "g").

and use the linear scaling $f$ for emission increases, matching the responses seen in Fig. 3. Note that we only apply these changes for $\mathrm{NO}_{\mathrm{x}}$ emissions; non-linearity in the $\mathrm{O}_{3}$ response to $\mathrm{CO}$ and $\mathrm{VOC}$ emission changes has been shown to be much smaller (Wu et al., 2009), and we therefore retain the linear scale factor, $f$, for these precursors.

Previous studies have suggested that the $\mathrm{O}_{3}$ response to $\mathrm{CH}_{4}$ emissions is approximately linear (Fiore et al., 2008). However, we find that an additional CTM run applying a $20 \%$ increase in $\mathrm{CH}_{4}$ abundance gives an $11 \%$ smaller $\mathrm{O}_{3}$ response over all regions than a run applying a $20 \% \mathrm{CH}_{4}$ decrease. Half of this $11 \%$ reduction, about $5 \%$, reflects the feedback of $\mathrm{CH}_{4}$ on its own lifetime (see, e.g. Prather, 1996), as a $20 \%$ increase in $\mathrm{CH}_{4}$ abundance requires a $5 \%$ smaller emission change than a $20 \%$ decrease. Nevertheless, it is clear that the response of surface $\mathrm{O}_{3}$ to changes in global $\mathrm{CH}_{4}$ abundance is similar to changes in regional $\mathrm{NO}_{\mathrm{x}}$ emissions, and we therefore choose to use the same scaling, given in Eq. (6), so that each successive $20 \%$ increase in $\mathrm{CH}_{4}$ abundance gives a $10 \%$ smaller $\mathrm{O}_{3}$ increase.

In summary, the final expression used is given by Eq. (1) with $f_{\mathrm{m}}=g_{\mathrm{m}}$ and with the scale factor $f_{i j}$ for precursor $i=$ $\mathrm{NO}_{\mathrm{x}}$ only given by:

$f_{i j}=\left\{\begin{array}{cl}f_{i j} & \text { if } \Delta \mathrm{O}_{3}(i, j, k)>0 \text { and } \Delta E_{i j}>0 \\ 2 f_{i j}-g_{i j} & \text { if } \Delta \mathrm{O}_{3}(i, j, k)>0 \text { and } \Delta E_{i j}<0 \\ g_{i j} & \text { otherwise }\end{array}\right.$
To provide a more critical test of the parameterization, we use it to reconstruct the results of new simulations with the FRSGC/UCI CTM using the RCP scenarios described in Sect. 2. Ozone precursor emission increases are largest in 2030 under the RCP 8.5 scenario, but the RCP 2.6 scenario shows large reductions by 2050 , so we explore these two cases which encompass the extremes for the scenarios. A comparison between the monthly mean regional $\mathrm{O}_{3}$ responses for a full simulation with the FRSGC/UCI CTM against that derived from the parameterization is shown in Fig. 4. In general the parameterization reproduces both the magnitude and the seasonality of the $\mathrm{O}_{3}$ responses very well. In the RCP 8.5 scenario there are small errors of up to $0.5 \mathrm{ppb}$ in wintertime over East Asia, and this likely reflects increased titration of $\mathrm{O}_{3}$ associated with the relatively large $(65 \%)$ increase in $\mathrm{NO}_{\mathrm{x}}$ emissions. Similarly, in the RCP 2.6 scenario the errors are largest in summertime over North America and Europe (reaching $0.8 \mathrm{ppb}$ and $0.5 \mathrm{ppb}$, respectively), and this is associated with the relatively large $\mathrm{NO}_{\mathrm{x}}$ emission reductions ( $70 \%$ and $50 \%$, respectively) over these regions. Elsewhere, where emission changes are smaller, the magnitude and the seasonality of the $\mathrm{O}_{3}$ responses in the full simulations are matched very well, suggesting that the parameterized approach used here is relatively robust.

Figure 4 also presents a regional source attribution for the $\mathrm{O}_{3}$ changes over each region in each scenario, simplified to 

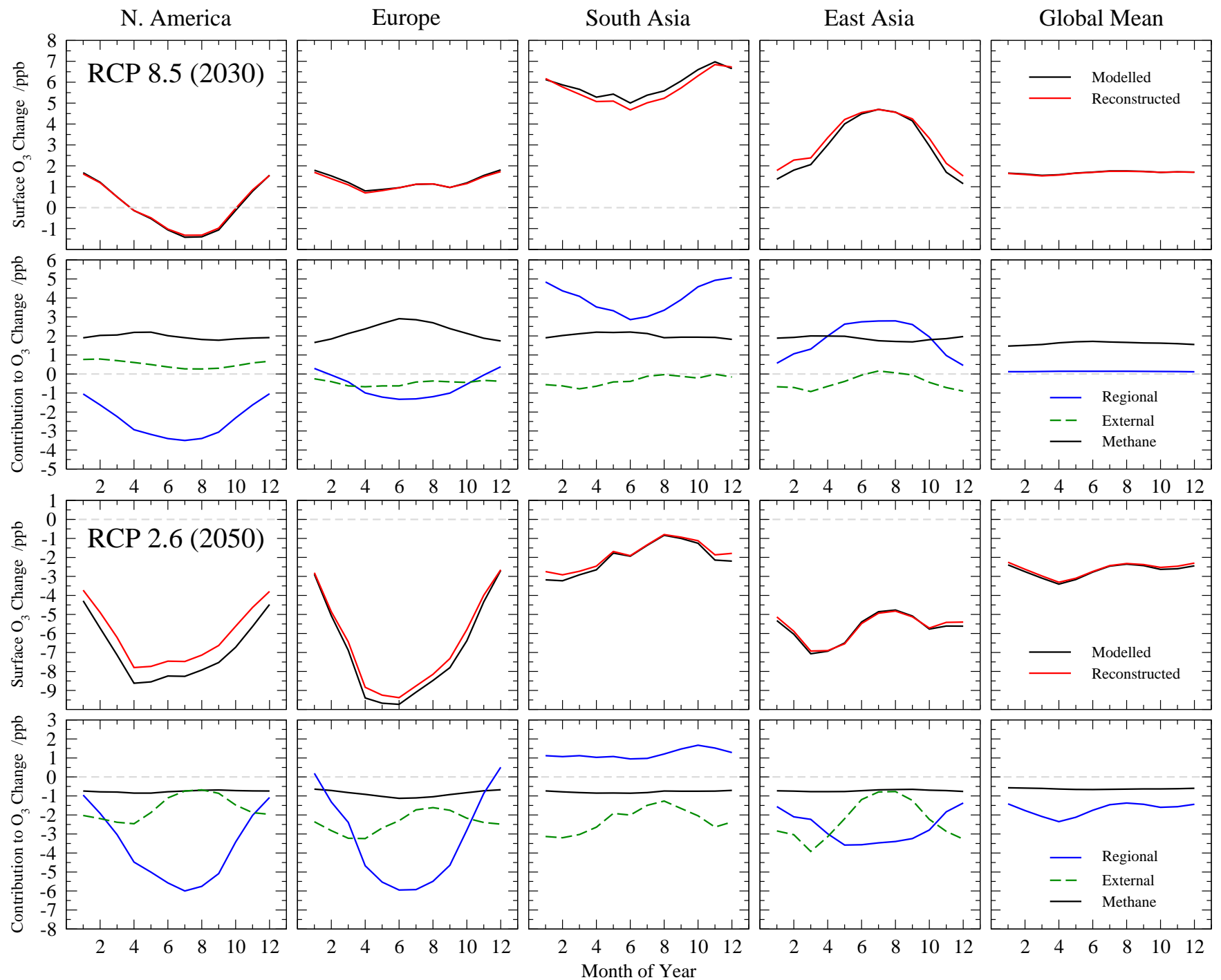

Fig. 4. Monthly regional mean surface $\mathrm{O}_{3}$ changes in the FRSGC/UCI CTM between 2000 and 2030 for the RCP 8.5 emissions (upper panel) and between 2000 and 2050 for the RCP 2.6 emissions (lower panel). The upper row of each panel shows the estimated $\mathrm{O}_{3}$ response compared with that from a full simulation, and the lower row shows the attribution of the $\mathrm{O}_{3}$ response to global $\mathrm{CH}_{4}$ changes (black) and to emission changes inside (blue) and outside (green) the source region.

show the response to $\mathrm{CH}_{4}$ abundance changes, regional emissions changes, and emission changes outside the focus region. This source attribution arises naturally from the simple combinatorial approach used here, and provides valuable additional insight without the need for tagged tracers in a full model simulation. The attribution reveals the extent to which the effects of regional emission reductions may be compensated by increases in emissions outside the region and in $\mathrm{CH}_{4}$, for example over North America in the RCP 8.5 scenario. While there is considerable redistribution of precursor emissions and surface $\mathrm{O}_{3}$ under this scenario, the net change in global surface $\mathrm{O}_{3}$ due to precursor emission changes is close to zero throughout the year; in effect, the changes in global $\mathrm{O}_{3}$ are caused almost entirely by the elevated abun- dance of atmospheric $\mathrm{CH}_{4}$ under this scenario. The attribution also provides important insight into the role of intercontinental transport in contributing to regional surface $\mathrm{O}_{3}$ changes, which counteract the effect of regional emission reductions over North America under RCP 8.5, and the effect of regional emission increases over South Asia under RCP 2.6.

Finally, we demonstrate that the approach works well across a range of models. Modelled and estimated surface $\mathrm{O}_{3}$ responses from four different models simulating the RCP 8.5 2030 scenario are shown in Fig. 5. Each model is treated independently, and the fractional emission changes along this RCP scenario are applied to the $\mathrm{O}_{3}$ responses from each model. Differences between the models reflect differences 

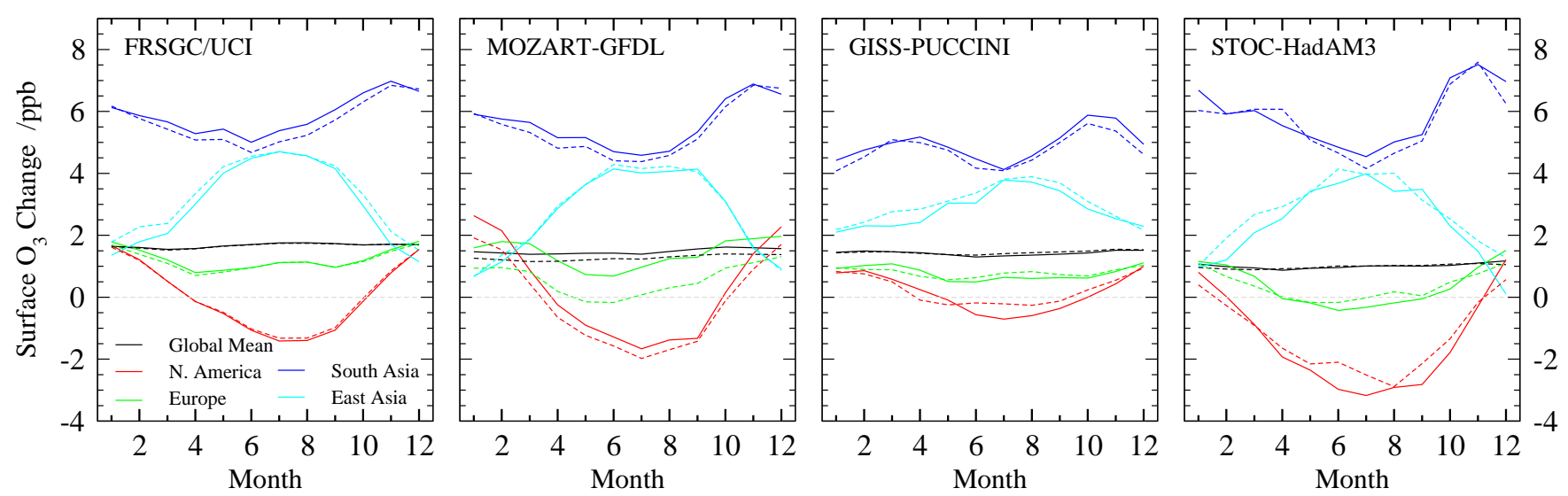

Fig. 5. Monthly regional mean surface $\mathrm{O}_{3}$ changes between 2000 and 2030 following the RCP 8.5 scenario with the FRSGC/UCI CTM, MOZART-GFDL CTM, GISS-PUCCINI GCM, and STOC-HadAM3 GCM (solid lines) and the parameterized estimate for each model (dashed lines).

Table 2. Chemistry transport models used to generate parameterization.

\begin{tabular}{lllll}
\hline CAM-CHEM & GEM-AQ & INCA-LMDz & MOZECH & TM5-JRC \\
EMEP & GISS-PUCCINI & LLNL-IMPACT & STOC-HadAM3 & UM-CAM \\
FRSGC/UCI & GMI & MOZART-GFDL & STOCHEM & \\
\hline
\end{tabular}

in chemistry and transport and in assumptions about the distribution and magnitude of emissions used in the present-day run. The estimates generally lie close to the true response for each model, with both the magnitude and seasonality of the responses reproduced well. The average root mean square (RMS) error in the estimates $(0.26 \mathrm{ppb})$ is much less than the RMS variation between the models (1.2 ppb). We conclude that the approach used here is suitable for estimation of surface $\mathrm{O}_{3}$ changes across the range of models contributing to HTAP.

\section{Anthropogenic contribution to historical trends}

To explore the regional anthropogenic contributions to past $\mathrm{O}_{3}$ trends, monthly mean surface $\mathrm{O}_{3}$ responses were extracted from each of the 14 models which contributed a sufficiently complete set of results for the standard HTAP simulations to allow use with the parameterization (see Table 2). Where results for global emissions perturbations were unavailable, the responses to rest-of-world perturbations were assumed to equal the ensemble mean responses for the models that did contribute results. The response to changes in tropospheric $\mathrm{CH}_{4}$ abundance was also included. We use the historical emissions of Lamarque et al. (2010) and derive regional and global surface $\mathrm{O}_{3}$ responses for each model by combining the responses for each precursor over each region based on the fractional emission change from year 2000 emissions. While emission data are available from 1850, we focus on the period from 1960 to present to minimize the er- rors introduced by applying very large emission reductions. Regional $\mathrm{NO}_{\mathrm{x}}$ emissions in 1960 were $40-45 \%$ lower over Europe and North America than in 2000, but were 75-80\% lower over South and East Asia, and the global $\mathrm{CH}_{4}$ abundance was $30 \%$ lower.

The changes in regional annual mean surface $\mathrm{O}_{3}$ relative to 2000 conditions are shown in Fig. 6. Regional increases since 1960 vary between 5 and $10 \mathrm{ppb}$, but the pathways differ substantially, with Europe and North America experiencing increases of about $0.25 \mathrm{ppb} \mathrm{yr}^{-1}$ until 1980, but then smaller increases that turn to a decline in the 1990s, while South and East Asia see steady increases of as much as $0.40 \mathrm{ppb} \mathrm{yr}^{-1}$. The uncertainty in these estimates as represented by the variation between models is relatively small, with a $1 \sigma$ variation of about $\pm 0.8 \mathrm{ppb}$ since 1960 . To test the robustness of these estimates, the FRSGC/UCI CTM was run with emissions representative of 1960 conditions. The error in estimates for the global and regional annual mean surface $\mathrm{O}_{3}$ response is typically less than $0.1 \mathrm{ppb}$, and reaches a maximum of $0.25 \mathrm{ppb}$ for East Asia, where $\mathrm{NO}_{\mathrm{x}}$ emissions were $75 \%$ smaller in 1960 than 2000, and thus where we expect to underestimate the $\mathrm{O}_{3}$ change. Nevertheless, this represents an underestimate of less than $3 \%$ of the calculated change of $8.4 \mathrm{ppb}$, and we conclude that the parameterization is capable of representing the full model simulations under these conditions.

Figure 6 also shows the contribution from changes in regional emissions, precursor emissions outside the region, and tropospheric $\mathrm{CH}_{4}$ abundance to the estimated regional $\mathrm{O}_{3}$ 

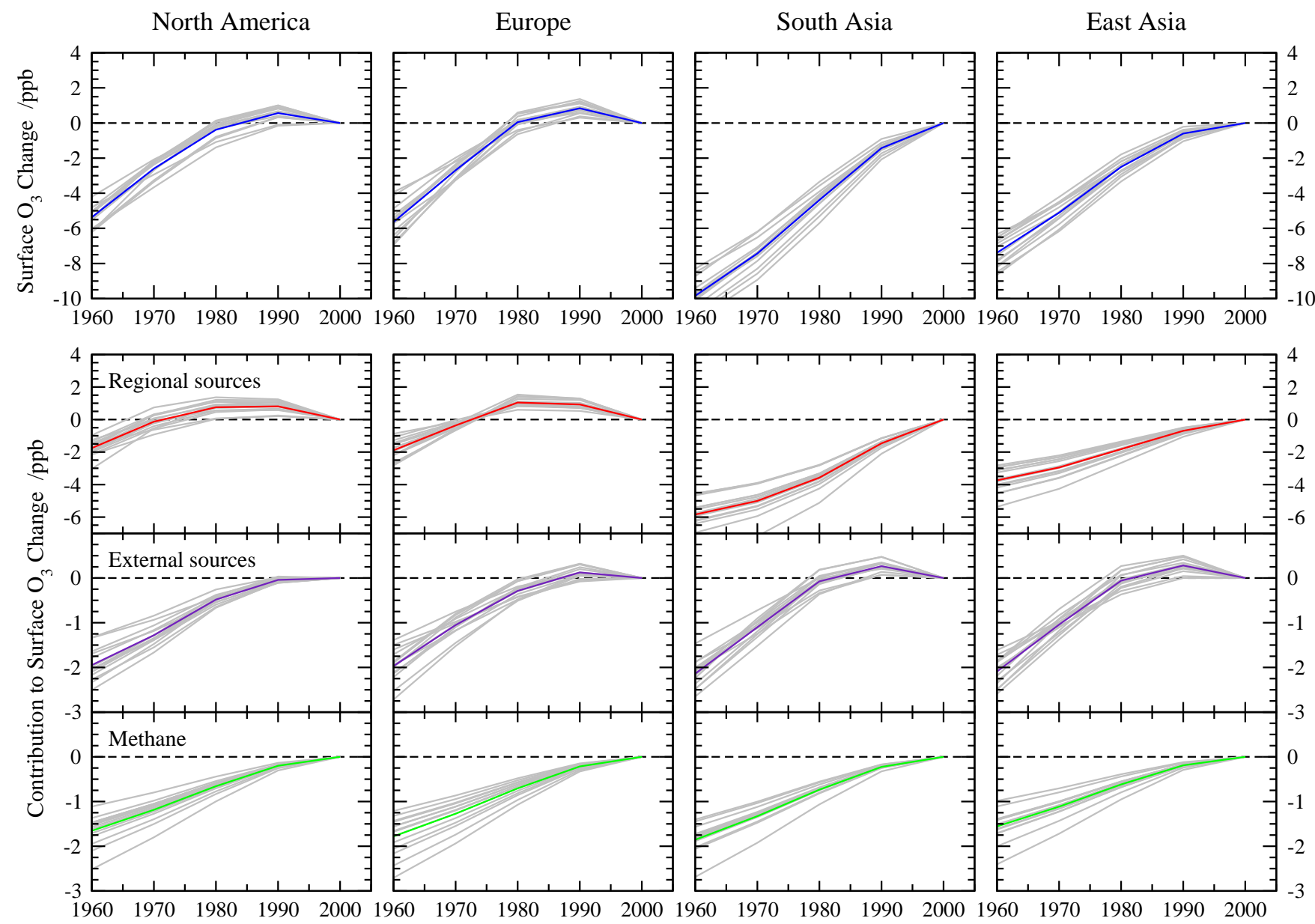

Fig. 6. Annual regional mean surface $\mathrm{O}_{3}$ changes relative to 2000 over each HTAP region following historical precursor emission changes between 1960 and 2000 (top row), and the contribution of regional anthropogenic sources, anthropogenic sources outside the region, and global methane changes (bottom row). Individual model responses are shown in grey and the mean of all 14 models is coloured.

changes on an annual mean basis. For Europe and North America the changes in regional and external precursor emissions have made a similar contribution since 1960, about $2 \mathrm{ppb}$, although this masks the faster rise and subsequent drop of $\mathrm{O}_{3}$ from regional sources. Over South and East Asia, regional emission changes contribute 4-6 ppb, more than $50 \%$ of the increase. Increases in atmospheric $\mathrm{CH}_{4}$ contribute to all regions relatively uniformly, averaging $1.5-1.9 \mathrm{ppb}$ since 1960, and this contributes about one third of the $\mathrm{O}_{3}$ increase seen over Europe and North America. Note the substantial uncertainty in the response to $\mathrm{CH}_{4}$ reflected in a factor of two difference between the most and least sensitive models, about $\pm 0.75 \mathrm{ppb}$ since 1960 . This reflects differences in chemical environment, particularly in the abundance of $\mathrm{OH}$, as noted elsewhere (e.g. Fiore et al., 2009). Nevertheless, the contribution to the uncertainty in the total $\mathrm{O}_{3}$ changes since 1960 remains small, only about $0.1 \mathrm{ppb}$ of the $1 \sigma$ variation, suggesting that models with stronger $\mathrm{O}_{3}$ responses to $\mathrm{CH}_{4}$ have weaker responses to other precursors.
These surface $\mathrm{O}_{3}$ changes due to growth in anthropogenic precursor emissions are compared with observed surface $\mathrm{O}_{3}$ trends by extracting $\mathrm{O}_{3}$ responses at sites with long-term measurements, see Fig. 7. The ensemble annual mean surface $\mathrm{O}_{3}$ matches the observations reasonably well at each location, but the large spread over the different models (as much as $\pm 16 \mathrm{ppb}$ at Mauna Loa) indicates that this apparent skill is somewhat illusory, hiding differences in annual and diurnal cycles as well as systematic biases due to process representation in the models and to sampling location on the different model grids. The general growth in $\mathrm{O}_{3}$ is matched well at Mauna Loa, remote from the main source regions considered here, with an average increase in $\mathrm{O}_{3}$ of about $0.2 \mathrm{ppb} \mathrm{yr}^{-1}$ between 1960 and 1990 that levels off over the past decade. The relatively strong interannual variability in the observations is absent from the parameterized trend which uses 2001 meteorology throughout, making direct comparison difficult, but the observed linear trend between 1974 and 2004 is $0.15 \mathrm{ppb} \mathrm{yr}^{-1}$ compared with $0.13 \mathrm{ppb} \mathrm{yr}^{-1}$ 

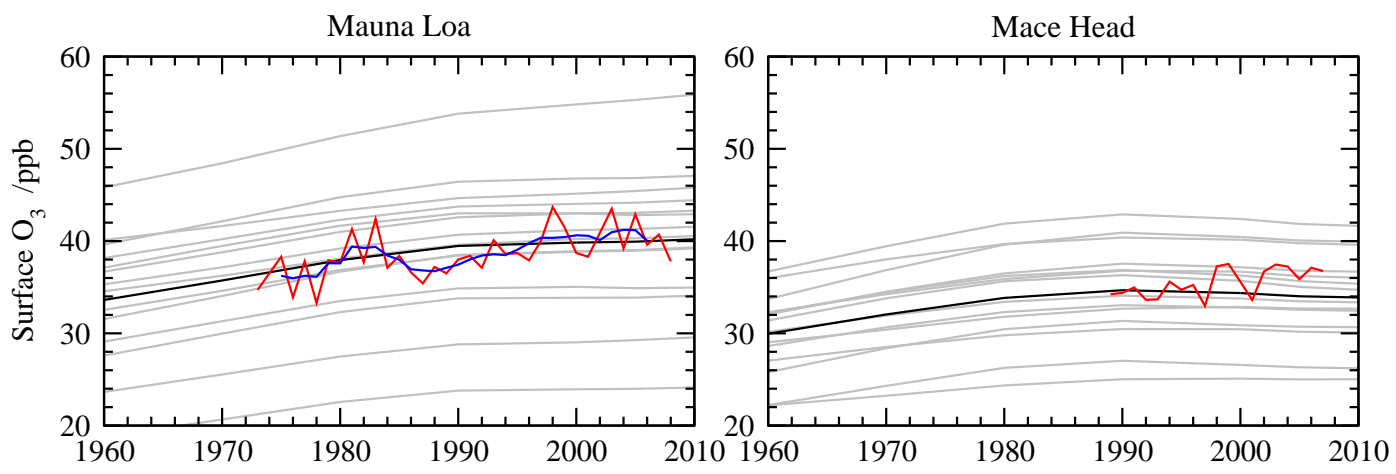

Fig. 7. Annual mean surface $\mathrm{O}_{3}$ trends at Mauna Loa and Mace Head between 1960 and 2010 for individual models (grey) and ensemble mean (black) against annual mean observed surface $\mathrm{O}_{3}$ (red). The 5-year running mean of the observations at Mauna Loa is shown in blue.

in the models. The contribution of $\mathrm{CH}_{4}$ increases in the models averages $0.05 \mathrm{ppb} \mathrm{yr}^{-1}$ over this period, about $40 \%$ of the trend at this site.

Closer to major continental regions the modelled trends are less well supported by observations. Unfiltered measurements at a coastal site, Mace Head, show an increase of about $0.17 \mathrm{ppb} \mathrm{yr}^{-1}$ between 1989 and 2007, and trends in clean baseline air at this site are thought to be as high as $0.31 \mathrm{ppb} \mathrm{yr}^{-1}$ (Derwent et al., 2007). Modelled $\mathrm{O}_{3}$ shows a positive trend of $0.08 \mathrm{ppb} \mathrm{yr}^{-1}$ in the $1980 \mathrm{~s}$, but the trend turns negative after the 1990s, reflecting reductions in European emissions, and averages $-0.03 \mathrm{ppb} \mathrm{yr}^{-1}$ over the measurement period. In the 1990 s, this trend is driven by the dominance of European and North American contributions ( -0.03 and $-0.04 \mathrm{ppb} \mathrm{yr}^{-1}$, respectively) over the contributions from Asia and from global $\mathrm{CH}_{4}$ changes (each $0.02 \mathrm{ppb} \mathrm{yr}^{-1}$ ). The difference from the observed trend may reflect weaknesses in emission assessments, but it may also reflect the spatial redistribution of emissions within regions which is not represented here (Vautard et al., 2006), or changes in shipping emissions which may have a substantial impact on coastal regions (e.g. Collins et al., 2008). Changes in natural sources, compounded by significant interannual meteorological variations, may also contribute to this discrepancy, and the influence of stratospheric $\mathrm{O}_{3}$ is thought to be significant (Hess and Zbinden, 2011). Further studies at regional scales accounting for spatial emission changes and meteorological variability are required to explain $\mathrm{O}_{3}$ changes at these continental locations, as previous studies have noted (e.g. Jonson et al., 2006).

\section{Application to future trends}

We now apply the parametric approach to explore changes in regional surface $\mathrm{O}_{3}$ along the four RCP emission scenarios. We do not account for any changes in climate, which would differ along the scenarios, but focus on the effects of anthropogenic precursor emission changes alone. Emis- sion changes by 2100 are large along several of the scenarios, so we focus on the period between 2000 and 2050, when changes are smaller and the resulting error in our estimates is less. The ensemble regional mean changes are presented in Fig. 8, and changes by 2050 are summarized in Table 3 along with an estimate of the uncertainty as represented by the $1 \sigma$ variation over the models. Under all four scenarios surface $\mathrm{O}_{3}$ falls over Europe and North America, although this fall is reversed over Europe after 2020 along RCP 8.5, driven not by increasing regional emissions but by increasing atmospheric $\mathrm{CH}_{4}$. Surface $\mathrm{O}_{3}$ increases over South Asia in all scenarios, although there is a large difference between RCP 8.5, where increases of more than $5 \mathrm{ppb}$ are seen by 2050, and RCP 6.0, where changes are close to zero. Over East Asia there is also a large variation, with increases in $\mathrm{O}_{3}$ until 2020 but subsequently decreases under the RCP 2.6 and 4.5 scenarios. It is clear that under all RCP scenarios except RCP 6.0 the greatest increases in surface $\mathrm{O}_{3}$ are over South Asia, and the large increases here are a major concern given the high population of the region and the influence of the region on wider tropospheric composition through strong convective lifting associated with the South Asian monsoon.

For comparison, the $\mathrm{O}_{3}$ responses along the SRES scenarios used in previous studies are also shown in Fig. 8 and Table 3. The $\mathrm{O}_{3}$ responses under all four RCP scenarios are substantially smaller than those under the SRES A1B, $\mathrm{A} 2$ and $\mathrm{B} 2$ scenarios, and all but the RCP 8.5 scenario are smaller than the mildest SRES B1 scenario. This is consistent with the findings of Lamarque et al. (2011) who explored $\mathrm{O}_{3}$ changes between 2000 and 2100 along the RCP pathways while accounting for changes in climate. Previous assessments of future surface $\mathrm{O}_{3}$ have typically focussed on the large responses expected under the extreme SRES A2 scenario (e.g. Prather et al., 2003), but the revised assessments of $\mathrm{O}_{3}$ precursor emissions under the RCP scenarios suggest that the A2 scenario was unduly pessimistic, as earlier studies have noted (Dentener et al., 2006).

The $\mathrm{O}_{3}$ responses for individual models are shown for RCP 2.6 and RCP 8.5 in Figs. 9 and 10. The responses 


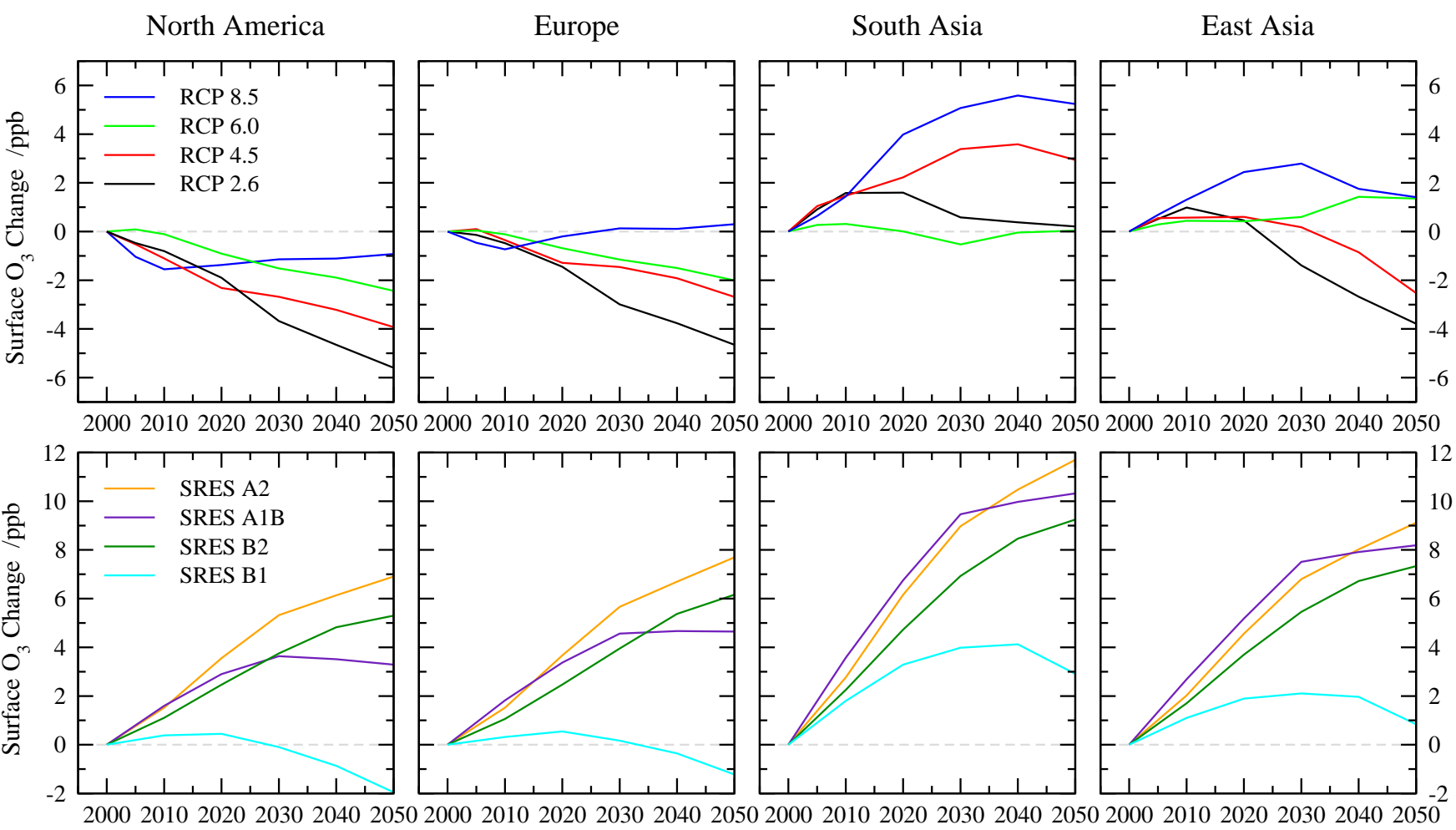

Fig. 8. Model ensemble annual regional mean surface $\mathrm{O}_{3}$ changes over the four HTAP regions from the parameterization following (a) the different RCP precursor emission pathways and (b) the SRES scenarios. The y-axis spans an $\mathrm{O}_{3}$ change of 14 ppb in each case to allow direct comparison of the magnitude of $\mathrm{O}_{3}$ changes.

Table 3. Annual regional mean surface $\mathrm{O}_{3}$ changes (in ppb) by 2050 along the RCP and SRES scenarios showing model ensemble mean and one standard deviation.

\begin{tabular}{lccccc}
\hline Scenario & N. America & Europe & S. Asia & E. Asia & \multicolumn{1}{c}{ Global } \\
\hline RCP 2.6 & $-5.6 \pm 0.8$ & $-4.7 \pm 0.7$ & $0.2 \pm 0.8$ & $-3.8 \pm 0.5$ & $-2.0 \pm 0.5$ \\
RCP 4.5 & $-3.9 \pm 0.8$ & $-2.7 \pm 0.5$ & $2.9 \pm 0.8$ & $-2.5 \pm 0.4$ & $-0.8 \pm 0.4$ \\
RCP 6.0 & $-2.4 \pm 0.7$ & $-2.0 \pm 0.5$ & $0.0 \pm 0.3$ & $1.4 \pm 0.4$ & $-0.4 \pm 0.2$ \\
RCP 8.5 & $-0.9 \pm 0.9$ & $0.3 \pm 0.8$ & $5.2 \pm 0.8$ & $1.4 \pm 0.6$ & $1.5 \pm 0.5$ \\
\hline \multicolumn{7}{l}{ SRES scenarios for comparison: } \\
SRES B1 & $-2.0 \pm 0.6$ & $-1.2 \pm 0.5$ & $2.9 \pm 0.6$ & $0.8 \pm 0.4$ & $0.8 \pm 0.3$ \\
SRES B2 & $5.3 \pm 0.5$ & $6.2 \pm 1.0$ & $9.2 \pm 0.7$ & $7.3 \pm 0.7$ & $4.3 \pm 0.5$ \\
SRES A1B & $3.3 \pm 0.7$ & $4.6 \pm 0.9$ & $10.3 \pm 1.0$ & $8.2 \pm 1.1$ & $4.5 \pm 0.4$ \\
SRES A2 & $6.9 \pm 0.7$ & $7.7 \pm 1.3$ & $11.7 \pm 0.8$ & $9.1 \pm 0.8$ & $6.2 \pm 0.7$ \\
\hline
\end{tabular}

are broadly similar, although there is a divergence in the results with time as the emissions and $\mathrm{CH}_{4}$ abundance change. Given that the models differ substantially in their formulation and assumptions, the spread of results provides a simple measure of the uncertainty in $\mathrm{O}_{3}$ responses. The largest $1 \sigma$ variability along the RCP scenarios by 2050 is about $\pm 0.8 \mathrm{ppb}$ although in a number of cases this is skewed by individual outlying results.

Figures 9 and 10 also provide a clear source attribution of $\mathrm{O}_{3}$ changes to changes in regional and extra-regional precur- sor emissions and $\mathrm{CH}_{4}$ abundance. While the largest contribution to regional $\mathrm{O}_{3}$ changes under most scenarios is from precursor emissions in the region itself, $\mathrm{O}_{3}$ transported from sources outside the region can make a substantial contribution that supplements or counteracts these changes. For example, over Europe in 2050 under the RCP 2.6 scenario local emission changes contribute to a reduction of $2 \mathrm{ppb} \mathrm{O}_{3}$ while changes elsewhere contribute an additional $1.5 \mathrm{ppb}$ reduction. The seasonality of these changes is notably different, as shown earlier in Fig. 4, with regional emission changes 

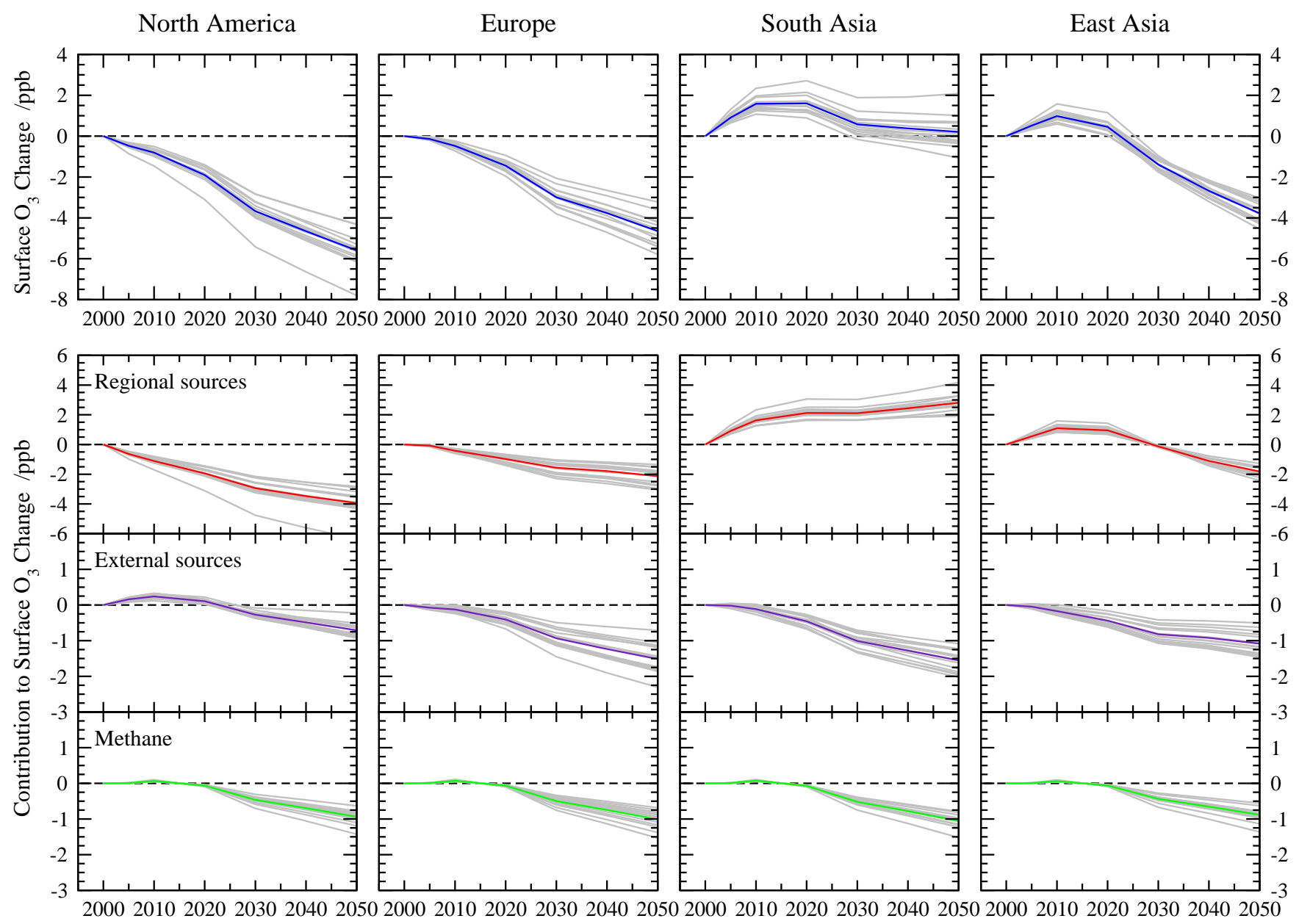

Fig. 9. Regional mean $\mathrm{O}_{3}$ changes along the RCP 2.6 scenario showing the ensemble mean (coloured line) and individual model responses (grey lines). A source attribution is presented for each region in the lower panels.

having the largest effect in mid-summer when photochemistry is most active, and imported $\mathrm{O}_{3}$ largest in spring. In contrast, over North America in 2020 under the RCP 8.5 scenario the reduction of $2.5 \mathrm{ppb}$ from regional emission reductions is partly offset by a $0.6 \mathrm{ppb}$ increase from emission changes outside the region. This source breakdown provides valuable insight into the potential of regional emission controls in coming decades under these scenarios.

Changes in $\mathrm{CH}_{4}$ abundance make a major contribution to $\mathrm{O}_{3}$ changes, particularly for the RCP 8.5 scenario where they increase $\mathrm{O}_{3} 2.5-3.0 \mathrm{ppb}$ by 2050 , effectively counteracting the benefits of the large precursor emission reductions over North America and Europe. Under this scenario $\mathrm{CH}_{4}$ abundance reaches $2740 \mathrm{ppb}$ by 2050 , a $56 \%$ increase over 2000 levels. The difference in $\mathrm{CH}_{4}$ between the RCP 2.6 and RCP 8.5 scenarios accounts for regional $\mathrm{O}_{3}$ differences of $3.3-3.9$ ppb $\mathrm{O}_{3}$ by 2050 , almost $75 \%$ of the $\mathrm{O}_{3}$ differences between these two scenarios (4.7-5.2 ppb). However, there is substantial uncertainty here as the response to $\mathrm{CH}_{4}$ differs between models by as much as a factor of two. The parameterization allows us to isolate the contribution of this uncertainty; for the RCP 8.5 scenario it contributes almost half of the $1 \sigma$ variation in the $\mathrm{O}_{3}$ response by 2050, 0.2$0.4 \mathrm{ppb}$. Removing the contribution from $\mathrm{CH}_{4}$ changes reduces the $1 \sigma$ variation over Europe from 0.77 to $0.43 \mathrm{ppb}$ and over the global domain from 0.55 to $0.30 \mathrm{ppb}$. Under the other RCP scenarios $\mathrm{CH}_{4}$ makes a far smaller contribution to the total uncertainty (typically less than 5\%), reflecting both the larger precursor emission reductions in these scenarios and the smaller changes in $\mathrm{CH}_{4}$. Nevertheless, it is clear that uncertainty in the response of $\mathrm{O}_{3}$ to $\mathrm{CH}_{4}$ can contribute substantially to uncertainty in the estimated $\mathrm{O}_{3}$ changes, and addressing this discrepancy between models should be a high priority for future model intercomparison studies.

The uncertainty in the $\mathrm{O}_{3}$ changes estimated here reflects only direct differences in chemical environment in the models under prescribed $\mathrm{CH}_{4}$ abundances, and $\mathrm{CH}_{4}$ emissions have not been explicitly considered. In reality, changes in $\mathrm{O}_{3}$ precursor emissions influence the build-up of $\mathrm{CH}_{4}$ through control of the $\mathrm{OH}$ radical, and thus have an indirect 

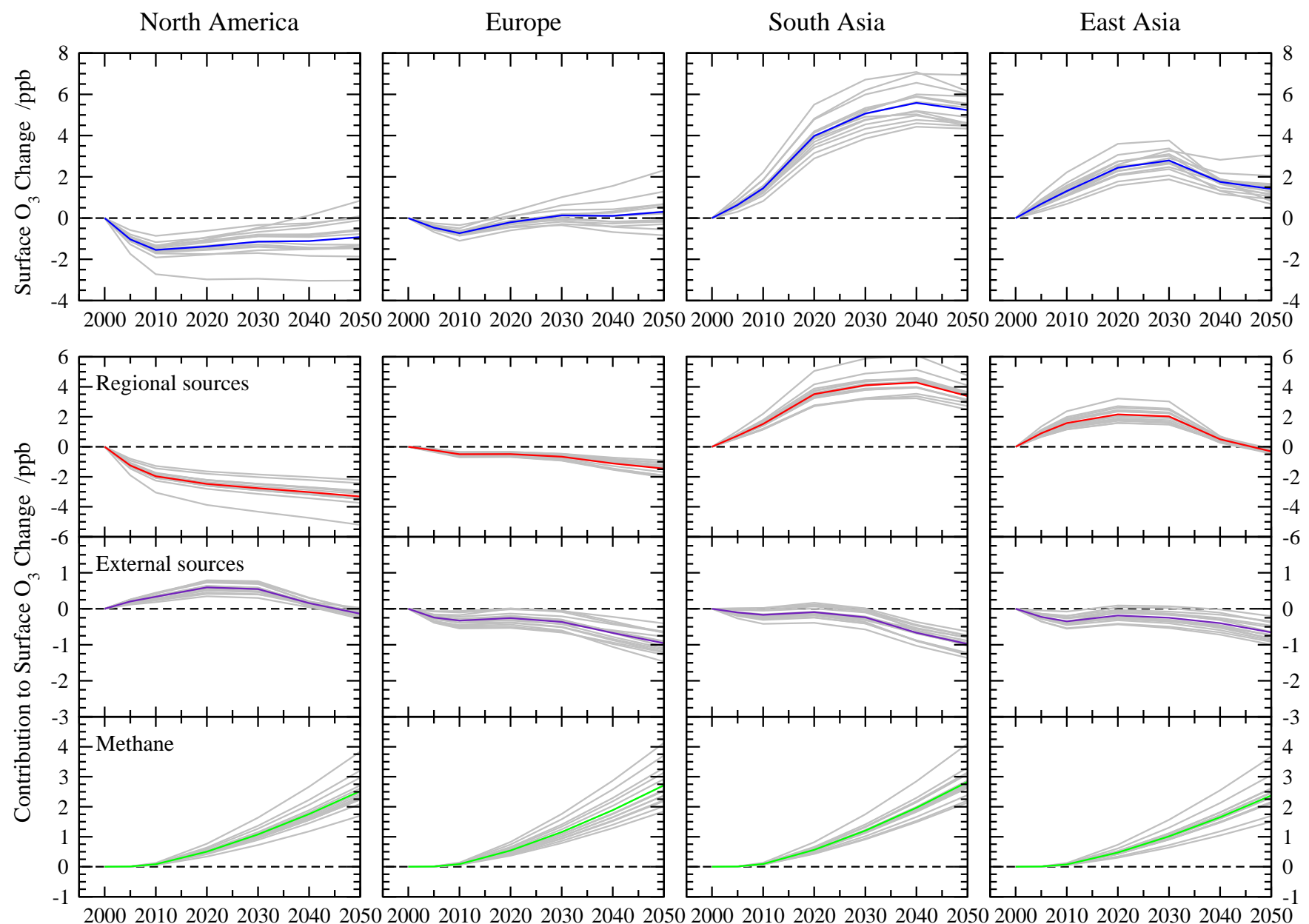

Fig. 10. As Fig. 9 for the RCP 8.5 scenario.

$\mathrm{O}_{3}$ response through altered $\mathrm{CH}_{4}$ abundance (Prather, 1996; Wild et al., 2001). This long-term $\mathrm{O}_{3}$ response has been quantified for the HTAP sensitivity studies to derive equilibrium responses (Fiore et al., 2009) but we do not attempt to correct for it under the transient emission scenarios used here. We have also assumed that fractional precursor emission changes can be applied to the present-day emissions in each model and have not attempted to normalise these to some standard values. Previous studies have shown that the effects of an emission perturbation are sensitive to the baseline emissions used (Collins et al., 2008), and this is likely to contribute further uncertainty in the spread of model results. The results may also be sensitive to model resolution, although we do not find any systematic differences at the resolutions used here $\left(1^{\circ} \times 1^{\circ}\right.$ to $\left.5^{\circ} \times 5^{\circ}\right)$ that stand out above other model differences. The multi-model studies of Dentener et al. (2006) found global surface $\mathrm{O}_{3}$ changes between 2000 and 2030 of $1.5 \pm 1.2$ and $-2.3 \pm 1.1 \mathrm{ppb}$ under current legislation (CLE) and maximum feasible reduction (MFR) scenarios; we estimate changes of $1.4 \pm 0.2$ and $-2.4 \pm 0.5 \mathrm{ppb}$ using the parameterization described here.
While the ensemble mean agreement is very good, the variation between models is much less. Although some of this can be attributed to the smaller number of models (14 vs. 26) and the consistency of approach (eliminating differences in scenario interpretation and implementation), it is clear that the $1 \sigma$ variation calculated here is less than that found in typical model intercomparisons, suggesting that the factors identified above contribute substantially to the variation seen in these studies.

The future changes in surface $\mathrm{O}_{3}$ described here do not include the effects of any changes in climate on atmospheric chemistry or transport. Previous studies have identified changes in continental $\mathrm{O}_{3}$ associated with faster $\mathrm{O}_{3}$ production under some climate scenarios (Jacob and Winner, 2009), and a consequent increase in the relative importance of $\mathrm{O}_{3}$ from regional sources over that transported from outside the region (Murazaki and Hess, 2006; Doherty et al., 2012). Other studies have noted that future changes in regional meteorology may alter the build up of surface $\mathrm{O}_{3}$ (e.g. Mickley et al., 2004), and that circulation changes may lead to increased influence from stratospheric $\mathrm{O}_{3}$ (Kawase et al., 

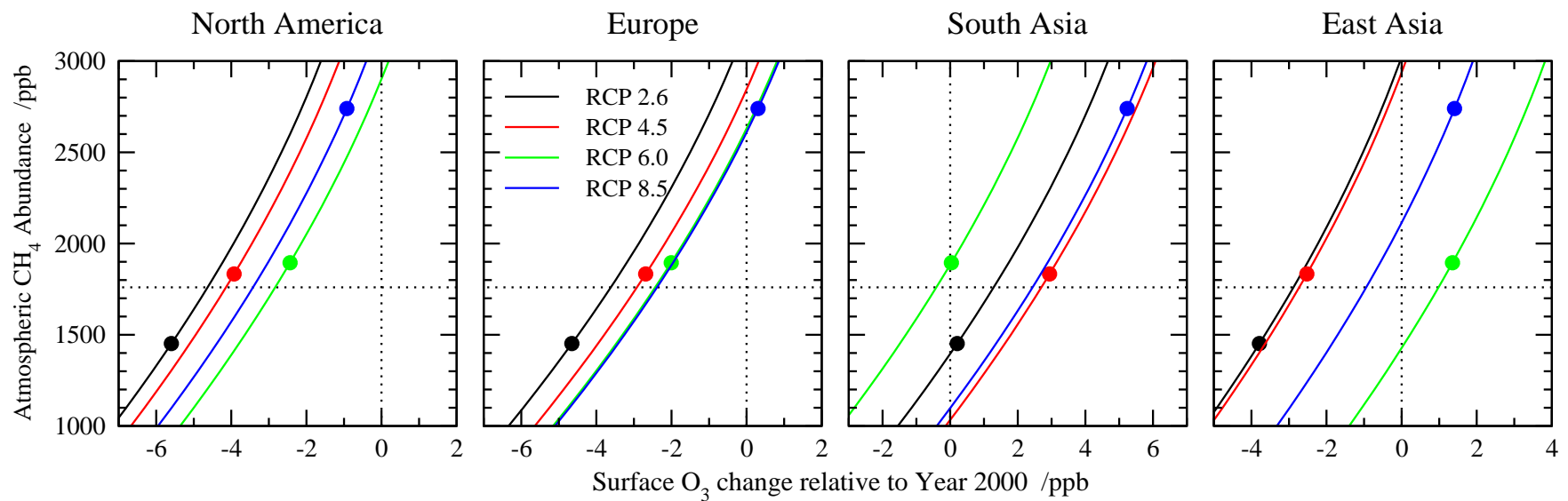

Fig. 11. Sensitivity of regional surface $\mathrm{O}_{3}$ in 2050 to the atmospheric $\mathrm{CH}_{4}$ abundance under each of the RCP scenarios. Circles mark the ensemble mean surface $\mathrm{O}_{3}$ response under each scenario, and curves show how this would change under different levels of $\mathrm{CH}_{4}$. Dashed lines mark $\mathrm{CH}_{4}$ and surface $\mathrm{O}_{3}$ for year 2000 .

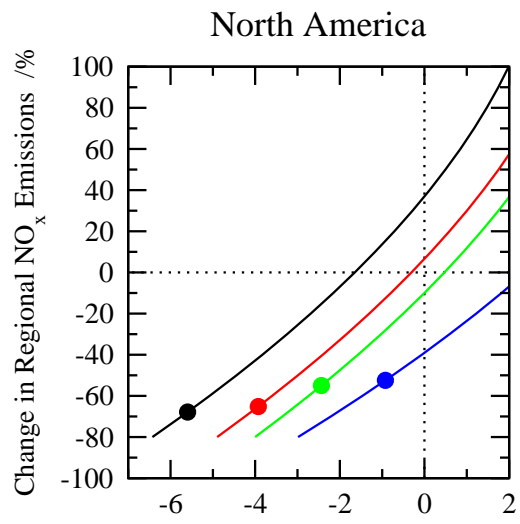

Europe

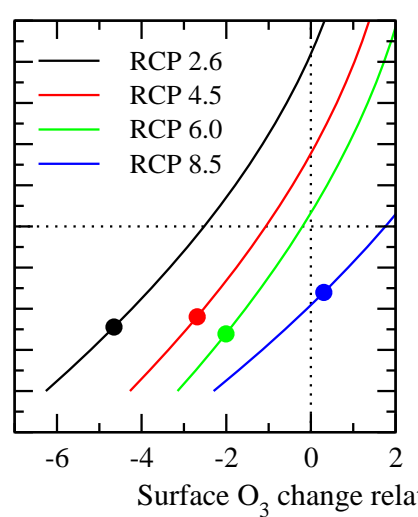

South Asia

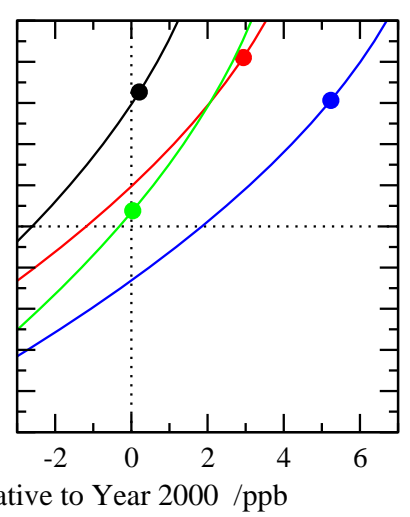

East Asia

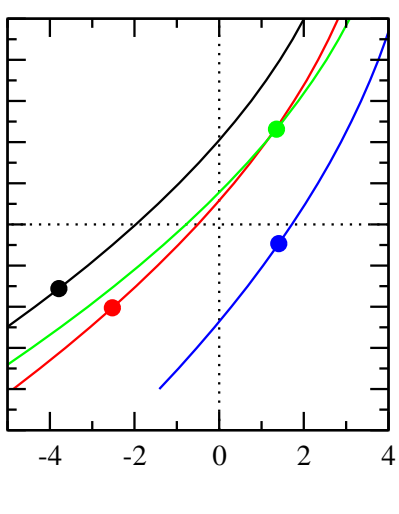

Fig. 12. Sensitivity of regional surface $\mathrm{O}_{3}$ in 2050 to regional $\mathrm{NO}_{\mathrm{x}}$ emissions under each of the RCP scenarios. Circles mark the ensemble mean surface $\mathrm{O}_{3}$ response under each scenario, and curves show how this would change for different regional $\mathrm{NO}_{\mathrm{x}}$ emissions. Dashed lines mark year 2000 conditions.

2011). We also neglect the role of meteorological variability in influencing surface $\mathrm{O}_{3}$ changes (Brown-Steiner and Hess, 2011). Over the large continental-scale regions used here the influence is found to be small (TF-HTAP, 2010; Doherty et al., 2012), but further studies are needed to confirm this.

\section{Applications for policy}

The combinatorial approach to estimating surface $\mathrm{O}_{3}$ responses applied here is easily inverted to provide information on the emission changes required to meet specific $\mathrm{O}_{3}$ targets over a particular region. This gives valuable insight into the sensitivity of regional surface $\mathrm{O}_{3}$ changes and provides a useful basis for decisions about emission controls. Figure 11 shows the annual ensemble mean $\mathrm{O}_{3}$ response in 2050 for each region under each of the RCP scenarios along with its sensitivity to the atmospheric abundance of $\mathrm{CH}_{4}$. The close proximity of the $\mathrm{O}_{3}$ response lines over North America and Europe highlight the similarity in regional emission controls over the four RCP scenarios; for a given $\mathrm{CH}_{4}$ abundance the $\mathrm{O}_{3}$ response over Europe between the scenarios differs by only $1.2 \mathrm{ppb}$. The much wider spread over South and East Asia (more than $4 \mathrm{ppb}$ ) reveals the larger differences in regional emissions between the scenarios. The figure provides guidance on the effect of atmospheric $\mathrm{CH}_{4}$ on regional $\mathrm{O}_{3}$. Under the RCP 8.5 scenario, regional surface $\mathrm{O}_{3}$ over Europe increases by $0.3 \mathrm{ppb}$ between 2000 and 2050; to ensure no increase over this period, the growth of $\mathrm{CH}_{4}$ would need to be limited to $2610 \mathrm{ppb}$, a $13 \%$ reduction in the $\mathrm{CH}_{4}$ increase expected along the RCP 8.5 scenario. Similarly, achieving a $1 \mathrm{ppb}$ decrease in $\mathrm{O}_{3}$ over Europe by 2050 would require that $\mathrm{CH}_{4}$ be limited to $2220 \mathrm{ppb}$, a $47 \%$ reduction in the expected $\mathrm{CH}_{4}$ increase. Limiting $\mathrm{CH}_{4}$ to its current 
atmospheric abundance would lead to a reduction of $2.4 \mathrm{ppb}$ over Europe under RCP 8.5. As the effect of $\mathrm{CH}_{4}$ changes on $\mathrm{O}_{3}$ is global, these reductions in the abundance of $\mathrm{CH}_{4}$ lead to $\mathrm{O}_{3}$ decreases of a similar magnitude over the other regions considered here.

The effect of regional $\mathrm{NO}_{\mathrm{x}}$ emission controls are illustrated in Fig. 12; the $\mathrm{CH}_{4}$ abundance and emissions of $\mathrm{CO}$ and VOC are assumed not to vary in this example. The $\mathrm{O}_{3}$ responses are truncated for regional emission reductions greater than $80 \%$ where the effect of the reductions is likely to be larger than estimated here due to greater nonlinear behaviour. The gradients of the $\mathrm{O}_{3}$ responses are greater over Europe than over North America, suggesting that a larger fractional $\mathrm{NO}_{\mathrm{x}}$ emission change is required to give a particular $\mathrm{O}_{3}$ increment. This may reflect the larger absolute emissions over North America, but may also reveal the greater importance of wintertime $\mathrm{O}_{3}$ titration over Europe. The curves provide guidance on the likely $\mathrm{O}_{3}$ benefits from $\mathrm{NO}_{\mathrm{x}}$ emission reductions. For example, under RCP 8.5 a $38 \%$ reduction in regional $\mathrm{NO}_{\mathrm{x}}$ emissions would be required to maintain European $\mathrm{O}_{3}$ in 2050 at 2000 levels, greater than the $32 \%$ reduction anticipated for the scenario. $\mathrm{A} 1 \mathrm{ppb} \mathrm{O}_{3}$ reduction would require an emission reduction of about $57 \%$, and a $2 \mathrm{ppb}$ reduction would require an emission reduction of $75 \%$. Clearly, meeting more stringent $\mathrm{O}_{3}$ targets than this would require intraregional cooperation focussing on reducing $\mathrm{CH}_{4}$ or on emission reductions in the developing world, otherwise reductions of more than a few ppb are not possible under the RCP 8.5 scenario from controlling European $\mathrm{NO}_{\mathrm{x}}$ emissions alone.

\section{Conclusions}

This study describes a simple parameterization for estimating regional surface $\mathrm{O}_{3}$ changes based on changes in regional anthropogenic emissions of $\mathrm{NO}_{\mathrm{x}}, \mathrm{CO}$ and VOCs and in global $\mathrm{CH}_{4}$ abundance using results from 14 independent global chemical transport models that contributed results to the HTAP model intercomparison. The approach successfully reproduces regional $\mathrm{O}_{3}$ changes through the year compared with full model simulations from a range of different models under conditions where precursor emissions do not deviate too greatly (typically $\pm 60 \%$ ) from those of the present day. While not replacing the need for full model simulations, the approach allows the effects of different emission scenarios to be explored and thus allows identification of scenarios of particular interest for further study. It naturally provides a regional source attribution for surface $\mathrm{O}_{3}$ changes without the need for tagging tracers in a full model simulation. An additional benefit is that the spread over the ensemble of model results provides a simple measure of uncertainty in regional $\mathrm{O}_{3}$ responses and their attribution. While the approach does not provide a rigorous quantification of process uncertainty, it allows identification of conditions and regions in which the results of current models differ substantially. The most important example examined here is that of atmospheric $\mathrm{CH}_{4}$, where the $\mathrm{O}_{3}$ response differs by more than a factor of two between models, and this makes the largest contribution to uncertainty in modelled surface $\mathrm{O}_{3}$ responses for scenarios where $\mathrm{CH}_{4}$ changes are large (e.g. RCP 8.5).

Application of the approach to historic anthropogenic emission trends captures some of the increase in observed surface $\mathrm{O}_{3}$ over the past 3-4 decades, but underestimates the magnitude of the $\mathrm{O}_{3}$ increases observed at continental sites. Previous studies have found similar results (e.g. Lamarque et al., 2010), suggesting that natural sources and changes in climate may have contributed significantly to surface $\mathrm{O}_{3}$ change. However, the approach is intended for continentalscale use and is not well suited for analysis of observations at particular locations as evolution of the regional distribution of emissions is not accounted for.

Application of the approach to future emission trends following the RCP scenarios demonstrates that substantial annual mean surface $\mathrm{O}_{3}$ reductions are expected by 2050 over most regions and scenarios, with the exception of South Asia where increases may be as large as $5 \mathrm{ppb}$. These $\mathrm{O}_{3}$ responses are contrasted with those from the SRES emission scenarios which show dramatic future increases in surface $\mathrm{O}_{3}$ driven by large increases in $\mathrm{O}_{3}$ precursors, consistent with the findings of Lamarque et al. (2011) with a coupled chemistry-climate model. This demonstrates that recent efforts to control precursor emissions are likely to have substantial benefits for future surface $\mathrm{O}_{3}$ if they are continued into the future.

Much of the difference between the extreme scenarios RCP 2.6 and RCP 8.5 is driven by differences in $\mathrm{CH}_{4}$ abundance. The importance of $\mathrm{CH}_{4}$ emission controls for influencing surface $\mathrm{O}_{3}$ has been highlighted by previous studies (e.g. Fiore et al., 2008), and the present study demonstrates the future importance of this, particularly for RCP 8.5. It also highlights that the $\mathrm{O}_{3}$ response to $\mathrm{CH}_{4}$ changes is a major area of uncertainty in current models, and that addressing this will significantly improve estimation of future $\mathrm{O}_{3}$ changes.

The uncertainty in future $\mathrm{O}_{3}$ changes represented here by the spread in results from different models reflects differences in transport and chemical environment in the models, but only captures part of the variation seen in previous model intercomparison studies. A more complete assessment of the uncertainty would require $\mathrm{CH}_{4}$ emissions to be considered and thus much longer, transient model simulations. Multiyear runs are also required to investigate the effects of interannual variability, and to quantify the effects of climate change on surface $\mathrm{O}_{3}$ responses, neither of which are considered here. Nevertheless, the approach used provides a good indication of where the largest uncertainties occur. The parameterization used here could be improved by conducting a further set of 20 runs with each of the contributing models that involve complete removal of anthropogenic emissions 
Table A1. Model ensemble mean annual surface $\mathrm{O}_{3}$ changes (in ppb) used in the present analysis.

\begin{tabular}{|c|c|c|c|c|c|c|}
\hline \multicolumn{2}{|c|}{ Model Scenario } & \multirow{2}{*}{$\begin{array}{c}\text { N. America } \\
36.125\end{array}$} & \multirow{2}{*}{$\begin{array}{l}\text { Europe } \\
37.816\end{array}$} & \multirow{2}{*}{$\begin{array}{l}\text { S. Asia } \\
39.562\end{array}$} & \multirow{2}{*}{$\begin{array}{l}\text { E. Asia } \\
35.614\end{array}$} & \multirow{2}{*}{$\begin{array}{l}\text { Global } \\
27.226\end{array}$} \\
\hline SR1 & Control run, mean $\mathrm{O}_{3}$ & & & & & \\
\hline \multicolumn{7}{|c|}{ Global $\mathrm{CH}_{4}$ abundance reduction } \\
\hline SR2 & $-20 \%$ global $\mathrm{CH}_{4}$ & -1.111 & -1.195 & -1.244 & -1.045 & -0.906 \\
\hline \multicolumn{7}{|c|}{ North American emission reductions } \\
\hline SR3NA & $-20 \% \mathrm{NO}_{\mathrm{x}}$ emissions & -0.749 & -0.212 & -0.104 & -0.125 & -0.127 \\
\hline SR4NA & $-20 \%$ VOC emissions & -0.285 & -0.108 & -0.046 & -0.065 & -0.059 \\
\hline SR5NA & $-20 \% \mathrm{CO}$ emissions & -0.104 & -0.061 & -0.035 & -0.038 & -0.027 \\
\hline \multicolumn{7}{|c|}{ European emission reductions } \\
\hline SR3EU & $-20 \% \mathrm{NO}_{\mathrm{x}}$ emissions & -0.075 & -0.445 & -0.147 & -0.115 & -0.073 \\
\hline SR4EU & $-20 \%$ VOC emissions & -0.087 & -0.448 & -0.090 & -0.115 & -0.078 \\
\hline SR5EU & $-20 \% \mathrm{CO}$ emissions & -0.030 & -0.113 & -0.033 & -0.037 & -0.021 \\
\hline \multicolumn{7}{|c|}{ South Asian emission reductions } \\
\hline SR3SA & $-20 \% \mathrm{NO}_{\mathrm{x}}$ emissions & -0.037 & -0.039 & -1.074 & -0.093 & -0.064 \\
\hline SR4SA & $-20 \%$ VOC emissions & -0.020 & -0.021 & -0.195 & -0.029 & -0.020 \\
\hline SR5SA & $-20 \%$ CO emissions & -0.019 & -0.019 & -0.097 & -0.025 & -0.015 \\
\hline \multicolumn{7}{|c|}{ East Asian emission reductions } \\
\hline SR3EA & $-20 \% \mathrm{NO}_{\mathrm{x}}$ emissions & -0.112 & -0.076 & -0.091 & -0.592 & -0.083 \\
\hline SR4EA & $-20 \%$ VOC emissions & -0.070 & -0.057 & -0.045 & -0.306 & -0.050 \\
\hline SR5EA & $-20 \% \mathrm{CO}$ emissions & -0.045 & -0.046 & -0.041 & -0.126 & -0.028 \\
\hline \multicolumn{7}{|c|}{ Rest-of-world emission reductions } \\
\hline SR3RW & $-20 \% \mathrm{NO}_{\mathrm{x}}$ emissions & -0.125 & -0.123 & -0.182 & -0.164 & -0.290 \\
\hline SR4RW & $-20 \%$ VOC emissions & -0.038 & -0.043 & -0.044 & -0.055 & -0.051 \\
\hline SR5RW & $-20 \% \mathrm{CO}$ emissions & -0.035 & -0.034 & -0.050 & -0.040 & -0.038 \\
\hline
\end{tabular}

Table A2. Regional emission changes and estimated $\mathrm{O}_{3}$ responses for 2050 from the RCP 8.5 scenario.

\begin{tabular}{lcccccc}
\hline Applied change & N. America & Europe & S. Asia & E. Asia & Rest-of-World & Global \\
\hline $\mathrm{CH}_{4}$ abundance & & & & & & $56.5 \%$ \\
$\mathrm{NO}_{\mathrm{x}}$ emissions & $-52.4 \%$ & $-32.1 \%$ & $61.3 \%$ & $-9.4 \%$ & $7.1 \%$ & \\
VOC emissions & $-57.2 \%$ & $-19.0 \%$ & $61.0 \%$ & $5.8 \%$ & $2.1 \%$ & \\
$\mathrm{CO}$ emissions & $-70.7 \%$ & $-50.7 \%$ & $34.5 \%$ & $-20.6 \%$ & $-5.7 \%$ & \\
\hline
\end{tabular}

Resultant annual mean regional surface $\mathrm{O}_{3}$ responses (ppb)

\begin{tabular}{llllll}
\hline $\mathrm{O}_{3}$ response & -0.91 & 0.32 & 5.25 & 1.42 & 1.49 \\
\hline
\end{tabular}

over each region. This would allow a more robust assessment of the nonlinear behaviour at large emission reductions and thus extend the range of applications. However, given the simplicity of the approach described here and the clear need for further improvement in the models, these refinements are not currently warranted. A similar approach could be applied to tropospheric ozone burdens to estimate changes in the contribution of ozone to radiative forcing, or to other pro- cesses of environmental importance such as nitrogen deposition. The method could also be extended through the depth of the troposphere to allow generation of chemical boundary conditions for regional modelling studies under future emission scenarios. 


\section{Appendix A}

\section{Parameterization example}

Ensemble mean annual surface $\mathrm{O}_{3}$ responses to $20 \%$ regional emission changes for the models used in this study are given in Table A1. Regional emission changes for 2050 from the RCP 8.5 scenario are shown in Table A2; applying these in Eq. (1) gives the mean $\mathrm{O}_{3}$ responses shown, and matches the results shown in Table 3. Note that the analysis presented in this paper uses monthly mean $\mathrm{O}_{3}$ responses to follow the seasonal cycle (e.g. see Fig. 5) and treats individual models separately so that the different sensitivities to wintertime titration can be accounted for appropriately. However, the influence of these conditions is relatively small, and the ensemble annual mean response can be estimated to better than $0.05 \mathrm{ppb}$ using the data in Table A1.

Acknowledgements. This work was performed under the Task Force on Hemispheric Transport of Air Pollution (www.htap.org) and we thank all contributors to the model intercomparison organised by HTAP.

Edited by: M. Kopacz

\section{References}

Akimoto, H.: Global air quality and pollution, Science, 302, 17161719, 2003.

Brown-Steiner, B. and Hess, P.: Asian influence on surface ozone in the United States: a comparison of chemistry, seasonality and transport mechanisms, J. Geophys. Res., 116, D17309, doi:10.1029/2011JD015846, 2011.

Collins, B., Sanderson, M. G., and Johnson, C. E.: Impact of increasing ship emissions on air quality and deposition over Europe by 2030, Meteorologische Zeitschrift, 18, 25-39, 2008.

Dentener, F., Stevenson, D., Ellingsen, K., van Noije, T., Schultz, M., Amann, M., Atherton, C., Bell, N., Bergmann, D., Bey, I., Bouwman, L., Butler, T., Cofala, J., Collins, B., Drevet, J., Doherty, R., Eickhout, B., Eskes, H., Fiore, A., Gauss, M., Hauglustaine, D., Horowitz, L., Isaksen, I. S. A., Josse, B., Lawrence, M., Krol, M., Lamarque, J.-F., Montanaro, V., Müller, J.-F., Pauch, V. H., Pitari, G., Pyle, J., Rast, S., Rodriguez, J., Sanderson, M., Savage, N. H., Shindell, D., Strahan, S., Szopa, S., Sudo, K., Van Dingenen, R., Wild, O., and Zeng, G.: The global atmospheric environment for the next generation, Environ. Sci. Technol., 40, 3586-3594, 2006.

Derwent, R. G., Simmonds, P. G., Manning, A. J., and Spain, T. G.: Trends over a 20-year period from 1987 to 2007 in surface ozone at the atmospheric research station, Mace Head, Ireland, Atmos. Environ., 41, 9091-9098, 2007.

Doherty, R. M., Shindell, D. T., Zeng, G., Wild, O., Collins, W. J., Stevenson, D. S., MacKenzie, I. A., Fiore, A. M., Dentener, F. J., Hess, P., Schultz, M. G., Derwent, R. G., and Keating, T. J.: The impact of climate change on surface ozone and intercontinental transport of ozone in a multi-model study, J. Geophys. Res., submitted, 2012.
Fiore, A. M., West, J. J., Horowitz, L. W., Naik, V., and Schwarzkopf, M. D.: Characterizing the tropospheric ozone response to methane emission controls and the benefits to climate and air quality, J. Geophys. Res., 113, D08307, doi:10.1029/2007JD009162, 2008.

Fiore, A. M., Dentener, F. J., Wild, O., Cuvelier, C., Schultz, M. G., Hess, P., Textor, C., Schulz, M., Doherty, R. M., Horowitz, L. W., MacKenzie, I. A., Sanderson, M. G., Shindell, D. T., Stevenson, D. S., Szopa, S., Van Dingenen, R., Zeng, G., Atherton, C., Bergmann, D., Bey, I., Carmichael, G., Collins, W. J., Duncan, B. N., Faluvegi, G., Folberth, G., Gauss, M., Gong, S., Hauglustaine, D., Holloway, T., Isaksen, I. S. A., Jacob, D. J., Jonson, J. E., Kaminski, J. W., Keating, T. J., Lupu, A., Marmer, E., Montanaro, V., Park, R. J., Pitari, G., Pringle, K. J., Pyle, J. A., Schroeder, S., Vivanco, M. G., Wind, P., Wojcik, G., Wu, S., and Zuber, A.: Multi-model estimates of intercontinental sourcereceptor relationships for ozone pollution, J. Geophys. Res., 114, D04301, doi:10.1029/2008JD010816, 2009.

Grewe, V., Tsati, E., and Hoor, P.: On the attribution of contributions of atmospheric trace gases to emissions in atmospheric model applications, Geosci. Model Dev., 3, 487-499, doi:10.5194/gmd-3-487-2010, 2010.

Hess, P. G. and Zbinden, R.: Stratospheric impact on tropospheric ozone variability and trends: 1990-2009, Atmos. Chem. Phys. Discuss., 11, 22719-22770, doi:10.5194/acpd-11-22719-2011, 2011.

Jacob, D. J. and Winner, D. A.: Effect of climate change on air quality, Atmos. Environ., 43, 51-63, doi:10.1016/j.atmosenv.2008.09.051, 2009.

Jonson, J. E., Simpson, D., Fagerli, H., and Solberg, S.: Can we explain the trends in European ozone levels?, Atmos. Chem. Phys., 6, 51-66, doi:10.5194/acp-6-51-2006, 2006.

Kawase, H., Nagashima, T., Sudo, K., and Nozawa, T.: Future changes in tropospheric ozone under Representative Concentration Pathways (RCPs), Geophys. Res. Lett., 38, L05801, doi:10.1029/2010GL046402, 2011.

Lamarque, J.-F., Bond, T. C., Eyring, V., Granier, C., Heil, A., Klimont, Z., Lee, D., Liousse, C., Mieville, A., Owen, B., Schultz, M. G., Shindell, D., Smith, S. J., Stehfest, E., Van Aardenne, J., Cooper, O. R., Kainuma, M., Mahowald, N., McConnell, J. R., Naik, V., Riahi, K., and van Vuuren, D. P.: Historical (1850-2000) gridded anthropogenic and biomass burning emissions of reactive gases and aerosols: methodology and application, Atmos. Chem. Phys., 10, 7017-7039, doi:10.5194/acp10-7017-2010, 2010.

Lamarque, J.-F., Kyle, G. P., Meinshausen, M., Riahi, K., Smith, S. J., van Vuuren, D. P., Conley, A. J., and Vitt, F.: Global and regional evolution of short-lived radiatively-active gases and aerosols in the Representative Concentration Pathways, Climatic Change, 109, 191-212, doi:10.1007/s10584-011-0155-0, 2011.

Lelieveld, J. and Dentener, F. J.: What controls tropospheric ozone?, J. Geophys. Res., 105, 3531-3551, 2000.

Lin, X., Trainer, M., and Liu, S. C.: On the nonlinearity of the tropospheric ozone production, J. Geophys. Res., 93, 15879-15888, 1988.

Masui, T., Matsumoto, K., Hijioka, Y., Kinoshita, T., Nozawa, T., Ishiwatari, S., Kato, E., Shukla, P. R., Yamagata, Y., and Kainuma, M.: An emission pathway for stabilization at $6 \mathrm{~W} \mathrm{~m}^{-2}$ radiative forcing, Climatic Change, 109, 59-76, 
doi:10.1007/s10584-011-0150-5, 2011.

Mickley, L. J., Jacob, D. J., Field, B. D., and Rind, D.: Effects of future climate change on regional air pollution episodes in the United States, Geophys. Res. Lett., 30, L24103, doi:10.1029/2004GL021216, 2004.

Murazaki, K. and Hess, P.: How does climate change contribute to surface ozone change over the United States?, J. Geophys. Res., 111, D05301, doi:10.1029/2005JD005873, 2006.

Oltmans, S. J, Lefohn, A. S., Harris, J. M., Galbally, I, Scheel, H. E., Bodeker, G., Brunke, E., Claude, H., Tarasick, D., Johnson, B. J., Simmonds, P., Shadwick, D., Anlauf, K., Hayden, K., Schmidlin, F., Fujimoto, T., Akagi, K., Meyer, C., Nichol, S., Davies, J., Redondas, A., and Cuevas, E.: Long-term changes in tropospheric ozone, Atmos. Environ., 40, 3156-3173, 2006.

Prather, M. J.: Timescales in atmospheric chemistry: Theory, GWPs for $\mathrm{CH}_{4}$ and $\mathrm{CO}$, and runaway growth, Geophys. Res. Lett., 23, 2597-2600, 1996.

Prather, M., Gauss, M., Berntsen, T., Isaksen, I., Sundet, J., Bey, I., Brasseur, G., Dentener, F., Derwent, R., Stevenson, D., Grenfell, L., Hauglustaine, D., Horowitz, L., Jacob, D., Mickley, L., Lawrence, M., von Kuhlmann, R., Müller, J.-F., Pitari, G., Rogers, H., Johnson, M., Pyle, J., Law, K., van Weele, M., and Wild, O.: Fresh air in the 21st century?, Geophys. Res. Lett., 30, 1100, doi:10.1029/2002GL016285, 2003.

Riahi, K., Rao, S., Krey, V., Cho, C., Chirkov, V., Fischer, G., Kindermann, G., Nakicenovic, N., and Rafaj, P.: RCP 8.5 - A scenario of comparatively high greenhouse gas emissions, Climatic Change, 109, 33-57, doi:10.1007/s10584-011-0149-y, 2011.

Sanderson, M. G., Dentener, F. J., Fiore, A. M., Cuvelier, C., Keating, T. J., Zuber, A., Atherton, C. S., Bergmann, D. J., Diehl, T., Doherty, R. M., Duncan, B. N., Hess, P., Horowitz, L. W., Jacob, D. J., Jonson, J. E., Kaminski, J. W., Lupu, A., MacKenzie, I. A., Mancini, E., Marmer, E., Park, R., Pitari, G., Prather, M. J., Pringle, K. J., Schroeder, S., Schultz, M. G., Shindell, D. T., Szopa, S., Wild, O., and Wind, P.: A multi-model study of the hemispheric transport and deposition of oxidised nitrogen, Geophys. Res. Lett., 35, L17815, doi:10.1029/2008GL035389, 2008.

Shindell, D. T., Chin, M., Dentener, F., Doherty, R. M., Faluvegi, G., Fiore, A. M., Hess, P., Koch, D. M., MacKenzie, I. A., Sanderson, M. G., Schultz, M. G., Schulz, M., Stevenson, D. S., Teich, H., Textor, C., Wild, O., Bergmann, D. J., Bey, I., Bian, H., Cuvelier, C., Duncan, B. N., Folberth, G., Horowitz, L. W., Jonson, J., Kaminski, J. W., Marmer, E., Park, R., Pringle, K. J., Schroeder, S., Szopa, S., Takemura, T., Zeng, G., Keating, T. J., and Zuber, A.: A multi-model assessment of pollution transport to the Arctic, Atmos. Chem. Phys., 8, 5353-5372, doi:10.5194/acp-8-5353-2008, 2008.
Sudo, K. and Akimoto, H.: Global source attribution of tropospheric ozone: Long-range transport from various source regions, J. Geophys. Res., 112, D12302, doi:10.1029/2006JD007992, 2007.

Task Force on Hemispheric Transport of Air Pollution (TF-HTAP): Hemispheric Transport of Air Pollution 2007, Air Pollut. Stud. 16, edited by: Keating, T. J. and Zuber, A., UNECE, Geneva, Switzerland, available at: http://www.htap.org/, 2007.

Task Force on Hemispheric Transport of Air Pollution (TF-HTAP): Hemispheric Transport of Air Pollution 2010, Air Pollut. Stud. 17, edited by: Dentener, F., Keating, T., and Akimoto, H., UNECE, Geneva, Switzerland, available at: http://www.htap.org/, 2010.

Thomson, A. M., Calvin, K. V., Smith, S. J., Kyle, G. P., Volke, A., Patel, P., Delgado-Arias, S., Bond-Lamberty, B., Wise, M. A., Clarke, L. E., and Edmonds, J. A.: RCP4.5: a pathway for stabilization of radiative forcing by 2100 , Climatic Change, 109, 77-94, doi:10.1007/s10584-011-0151-4, 2011.

van Vuuren, D. P., Stehfest, E., den Elzen, M. G. J., Kram, T., van Vliet, J., Deetman, S., Isaac, M., Klein Goldewijk, K., Hof, A., Mendoza Beltran, A., Oostenrijk, R., and van Ruijven, B.: RCP2.6: exploring the possibility to keep global mean temperature increase below $2^{\circ} \mathrm{C}$, Climatic Change, 109, 95-116, doi:10.1007/s10584-011-0152-3, 2011.

Vautard, R., Szopa, S., Beekmann, M., Menut, L., Hauglustaine, D. A., Rouil, L., and Roemer, M.: Are decadal anthropogenic emission reductions in Europe consistent with surface ozone observations?, Geophys. Res. Lett., 33, L13810, doi:10.1029/2006GL026080, 2006.

Wild, O., Prather, M. J., and Akimoto, H.: Indirect long-term global cooling from $\mathrm{NO}_{\mathrm{x}}$ emissions, Geophys. Res. Lett., 28, 1719$1722,2001$.

Wild, O., Sundet, J. K., Prather, M. J., Isaksen, I. S. A., Akimoto, H., Browell, E. V., and Oltmans, S. J.: CTM Ozone Simulations for Spring 2001 over the Western Pacific: Comparisons with TRACE-P lidar, ozonesondes and TOMS columns, J. Geophys. Res., 108, 8826, doi:10.1029/2002JD003283, 2003.

Wu, S., Duncan, B. N., Jacob, D. J., Fiore, A. M., and Wild, O.: Chemical nonlinearities in relating intercontinental ozone pollution to anthropogenic emissions, Geophys. Res. Lett., 36, L05806, doi:10.1029/2008GL036607, 2009. 